\title{
Clotting factor concentrates given to prevent bleeding and bleeding-related complications in people with hemophilia $A$ or B (Review)
}

\author{
Iorio A, Marchesini E, Marcucci M, Stobart K, Chan AKC
}

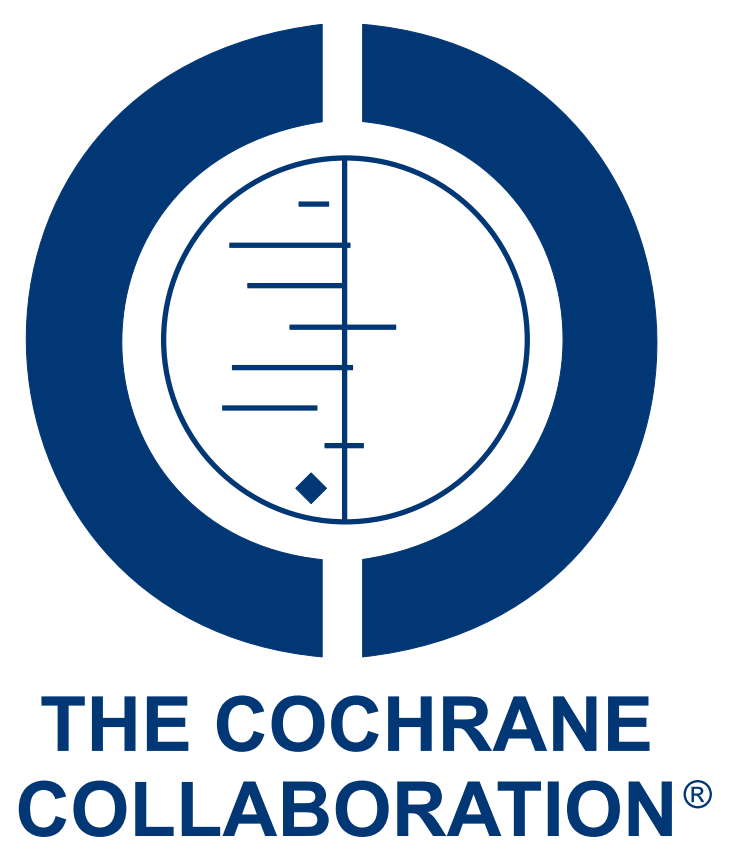

This is a reprint of a Cochrane review, prepared and maintained by The Cochrane Collaboration and published in The Cochrane Library 2011, Issue 9

http://www.thecochranelibrary.com

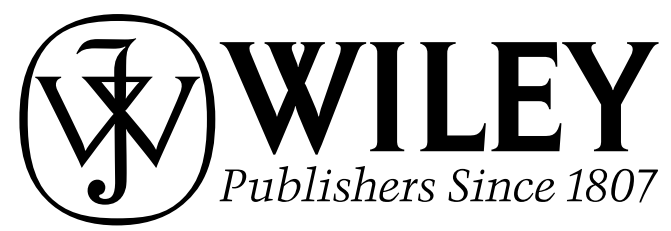

Clotting factor concentrates given to prevent bleeding and bleeding-related complications in people with hemophilia A or B (Review) Copyright $\odot 201$ I The Cochrane Collaboration. Published by John Wiley \& Sons, Ltd. 
TABLE OF CONTENTS

HEADER

ABSTRACT

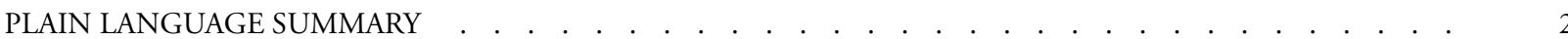

BACKGROUND . . . . . . . . . . . . . . . . . . . . . . . . . . . . . . . . . . . . . .

OBJECTIVES . . . . . . . . . . . . . . . . . . . . . . . . . . . . . . . . . . . . . . . . . . . . . .

METHODS . . . . . . . . . . . . . . . . . . . . . . . . . . . . . . . . . . . . . .

RESULTS . . . . . . . . . . . . . . . . . . . . . . . . . . . . . . . . . . . . . 5

Figure 1. . . . . . . . . . . . . . . . . . . . . . . . . . . . . . . . . . . . 7

Figure 2. . . . . . . . . . . . . . . . . . . . . . . . . . . . . . . . . . . . . .

DISCUSSION . . . . . . . . . . . . . . . . . . . . . . . . . . . . . . . . . . . . . . . . . . . . . .

AUTHORS' CONCLUSIONS . . . . . . . . . . . . . . . . . . . . . . . . . . . . . . . . . . . . . .

ACKNOWLEDGEMENTS . . . . . . . . . . . . . . . . . . . . . . . . . . . . . . . . . . . . . . . . 14

REFERENCES . . . . . . . . . . . . . . . . . . . . . . . . . . . . . . . . . . . . . . . . 14

CHARACTERISTICS OF STUDIES . . . . . . . . . . . . . . . . . . . . . . . . . . . . . . . . . . . . .

DATA AND ANALYSES . . . . . . . . . . . . . . . . . . . . . . . . . . . . . . . . . . . 26

Analysis 1.1. Comparison 1 Standard prophylaxis versus placebo (factor VIII concentrate (post-infusion level), Outcome 1 Bleed frequency. . . . . . . . . . . . . . . . . . . . . . . . . . . . . . . . . . . . . . . . . . . . . . . . $\quad 27$

Analysis 1.2. Comparison 1 Standard prophylaxis versus placebo (factor VIII concentrate (post-infusion level), Outcome 2 Morbidity (length of stay).

Analysis 2.1. Comparison 2 Standard prophylaxis versus on-demand treatment (factor VIII concentrate), Outcome 1 Bleed frequency.

Analysis 2.2. Comparison 2 Standard prophylaxis versus on-demand treatment (factor VIII concentrate), Outcome 2 Joint bleeding.

Analysis 2.3. Comparison 2 Standard prophylaxis versus on-demand treatment (factor VIII concentrate), Outcome 3 Joint function protection.

Analysis 2.4. Comparison 2 Standard prophylaxis versus on-demand treatment (factor VIII concentrate), Outcome 4 Quality of Life.

Analysis 2.5. Comparison 2 Standard prophylaxis versus on-demand treatment (factor VIII concentrate), Outcome 5 Factor concentrate usage [x1000 IU].

Analysis 2.6. Comparison 2 Standard prophylaxis versus on-demand treatment (factor VIII concentrate), Outcome 6 Adverse events.

Analysis 3.1. Comparison 3 Standard prophylaxis versus alternative prophylaxis (factor VIII concentrate (post-infusion level), Outcome 1 Bleed frequency.

Analysis 4.1. Comparison 4 Standard prophylaxis versus alternative prophylaxis (factor VIII concentrate), Outcome 1 Bleed frequency.

Analysis 4.2. Comparison 4 Standard prophylaxis versus alternative prophylaxis (factor VIII concentrate), Outcome 2 Clotting factor concentrate usage [x1000].

Analysis 5.1. Comparison 5 Standard prophylaxis versus alternative prophylaxis (factor IX concentrate), Outcome 1 Bleed frequency.

ADDITIONAL TABLES . . . . . . . . . . . . . . . . . . . . . . . . . . . . . . . . . . . 34

APPENDICES . . . . . . . . . . . . . . . . . . . . . . . . . . . . . . . . . . . . . . . . . . . 40

WHAT'S NEW . . . . . . . . . . . . . . . . . . . . . . . . . . . . . . . . . . . . . . . . . . . . . . 43

HISTORY . . . . . . . . . . . . . . . . . . . . . . . . . . . . . . . . . . . . . . . . 44

CONTRIBUTIONS OF AUTHORS . . . . . . . . . . . . . . . . . . . . . . . . . . . . . . . . . . . . . . . . . . . 4.44

DECLARATIONS OF INTEREST . . . . . . . . . . . . . . . . . . . . . . . . . . . . . . . . . . . . . . 45

SOURCES OF SUPPORT . . . . . . . . . . . . . . . . . . . . . . . . . . . . . . . . . . . . . . 45

DIFFERENCES BETWEEN PROTOCOL AND REVIEW . . . . . . . . . . . . . . . . . . . . . . . . . . . 45

INDEX TERMS . . . . . . . . . . . . . . . . . . . . . . . . . . . . . . . . . . . . . . . . . . . . . . . 45

Clotting factor concentrates given to prevent bleeding and bleeding-related complications in people with hemophilia A or B (Review)

Copyright $\odot 2011$ The Cochrane Collaboration. Published by John Wiley \& Sons, Ltd. 


\title{
[Intervention Review]
}

\section{Clotting factor concentrates given to prevent bleeding and bleeding-related complications in people with hemophilia $A$ or B}

\author{
Alfonso Iorio ${ }^{1}$, Emanuela Marchesini ${ }^{2}$, Maura Marcucci $^{2}$, Kent Stobart ${ }^{3}$, Anthony KC Chan ${ }^{4}$ \\ ${ }^{1}$ Clinical Epidemiology and Biostatistic Department, McMaster University, Hamilton, Canada. ${ }^{2}$ Department of Internal Medicine, \\ University of Perugia, Perugia, Italy. ${ }^{3}$ Northern Alberta Children's Cancer Program, Department of Pediatrics, University of Alberta, \\ Edmonton, Canada. ${ }^{4}$ Division of Pediatric Hematology/Oncology, Health Sciences Centre, McMaster University, Hamilton, Canada \\ Contact address: Alfonso Iorio, Clinical Epidemiology and Biostatistic Department, McMaster University, 1280 Main Street West, \\ CRL - 140, Hamilton, ON, L8S 4K1, Canada. iorioa@mcmaster.ca.
}

Editorial group: Cochrane Cystic Fibrosis and Genetic Disorders Group.

Publication status and date: New search for studies and content updated (conclusions changed), published in Issue 9, 2011.

Review content assessed as up-to-date: 9 July 2011.

Citation: Iorio A, Marchesini E, Marcucci M, Stobart K, Chan AKC. Clotting factor concentrates given to prevent bleeding and bleeding-related complications in people with hemophilia A or B. Cochrane Database of Systematic Reviews 2011, Issue 9. Art. No.: CD003429. DOI: 10.1002/14651858.CD003429.pub4.

Copyright (C) 2011 The Cochrane Collaboration. Published by John Wiley \& Sons, Ltd.

\section{A B S T R A C T}

\section{Background}

The hallmark of severe hemophilia is recurrent bleeding into joints and soft tissues with progressive joint damage, notwithstanding ondemand treatment. Prophylaxis has long been used but not universally adopted because of medical, psychosocial, and cost controversies.

\section{Objectives}

To determine the effectiveness of clotting factor concentrate prophylaxis in the management of people with hemophilia A or B.

\section{Search methods}

We searched the Cochrane Cystic Fibrosis and Genetic Disorders Group's Coagulopathies Trials Register. In addition, we searched major electronic databases (MEDLINE, EMBASE, CENTRAL), handsearched relevant journals and abstract books and reference lists of relevant articles.

Last search of Group's Coagulopathies Trials Register: 07 April 2011.

\section{Selection criteria}

Randomised controlled trials and quasi-randomised controlled trials evaluating people with severe hemophilia A or hemophilia B receiving prophylactic clotting factor concentrates.

\section{Data collection and analysis}

Two authors independently reviewed studies for eligibility, assessed risk of bias and extracted data.

Clotting factor concentrates given to prevent bleeding and bleeding-related complications in people with hemophilia A or B (Review)

Copyright $\odot 201$ I The Cochrane Collaboration. Published by John Wiley \& Sons, Ltd. 


\section{Main results}

Six studies (including 142 participants) were eligible for inclusion. Two compared three-times-a-week prophylactic administration with on-demand treatment in children with hemophilia. Pooled results from these two studies showed a rate ratio of 0.30 ( $95 \%$ confidence interval; 0.12 to 0.76 ) for all bleedings and 0.22 (95\% confidence interval 0.08 to 0.63 ) for joint bleedings favouring prophylaxis. Results on the number of patients with preserved joints after three to seven years of follow-up were not pooled due to significant heterogeneity. Three of the remaining four studies evaluated hemophilia A; one showed a statistically significant decrease in frequency of joint bleeds with prophylaxis compared to placebo, with a rate difference of -10.73 (95\% confidence interval -16.55 to -4.91 ) bleeds per year. Two studies compared two prophylaxis regimens, failing to demonstrate an advantage of one regimen over the other in terms of bleeding frequency. The fourth study evaluated hemophilia B and showed fewer joint bleeds with weekly (15 IU/kg) versus bi-weekly $(7.5 \mathrm{IU} / \mathrm{kg})$ prophylaxis, rate difference -3.30 (95\% confidence interval -5.50 to -1.10$)$ bleeds per year. Non-significant increases in both inhibitor and infectious complications were observed in patients on prophylaxis, which occurred more often when using longterm venous access.

\section{Authors' conclusions}

There is strong evidence from randomised controlled trials and observational trials that prophylaxis preserves joint function in children with hemophilia as compared to on-demand treatment. There is insufficient evidence from randomised controlled trials to confirm the observational evidence that prophylaxis decreases bleeding and related complications in patients with existing joint damage. Welldesigned randomised controlled trials and prospective observational controlled studies are needed to establish the best prophylactic regimen and to assess the effectiveness of prophylactic clotting factor concentrates in adult patients.

\section{PLAIN LANGUAGE SUMMARY}

\section{Regular clotting factor replacement therapy to prevent joint disease in people with severe hemophilia A or B}

Hemophilia A and B are X-linked inherited bleeding disorders, in which the major clinical problem is repeated bleeding into joints. As this disorder progresses, joints become deformed and movement limited. Current therapy for treating and preventing bleeding includes plasma-derived or recombinant clotting factor concentrates. This review includes six randomised controlled trials. Two compare the regular use of clotting factor concentrates to prevent joint bleeds with their use 'on demand'. Four compare different regimens of regular use in children and adults with hemophilia. It was clearly evident that preventative therapy, as intravenous infusion of factor concentrate repeated more times a week and started early in childhood was able to reduce joint deterioration as compared to treatment administered after bleeding occurred. This favourable effect is due to a consistent reduction in total bleeds and hemarthrosis (bleeding into joints) and leads to a significant improvement in quality of life. Preventative therapy is linked to an increased factor usage and cost of treatment. We found weaker evidence (due to lack of data) to show preventative therapy reduced joint deterioration when treatment is started after joint damage has been established. Further studies are needed to establish the best preventative regimen, i.e. for example starting time, dosage frequency, minimally effective dose.

\section{B A C K G R O U N D}

Hemophilia is an X-linked bleeding disorder due to a coagulation factor deficiency (factor VIII for Hemophilia A and factor IX for Hemophilia B) and is classified according to clotting factor level: severe (with a baseline coagulation factor level of less than $1 \%$ of normal); moderate (with clotting factor levels of $1 \%$ to $5 \%$ ); and mild (with a clotting factor greater than 5\%).

People with moderate and mild haemophilia bleed rarely, and often only after trauma or in association with invasive procedures.
The frequency and severity of bleeding is greatest in people with severe hemophilia A or B, in which recurrent and often spontaneous bleeding into joints and soft tissues (since early childhood) is the hallmark of severity. The consequence of recurrent joint bleeding is the development of different degrees of haemophilic arthropathy.

The availability of clotting factor concentrates has radically changed the treatment of people with hemophilia, with a sig- 
nificant improvement of morbidity, mortality and quality of life (QoL) (Lusher 1997). Since the introduction of clotting factor concentrates, the early on-demand treatment for acute bleeding episodes is now common practice. This has resulted in a decrease in the number of joint deformities with respect to untreated or minimally-treated patients (Ahlberg 1965; Hilgartner 1974).

However, observation of the natural history of haemophilic arthropathy in people on long-term on-demand treatment shows that this regimen is clearly sub-optimal. A milestone study in 1994 reported the results of a longitudinal observation of 477 males under 25 years of age with severe hemophilia A without inhibitors who were followed up for six years (Aledort 1994). Patients treated on demand showed a progressive deterioration of their joint function in some or all of the joints examined. Repeated bleeding in the joints has been indicated as the mechanism which, through abnormal proliferation of the synovial tissue, leads to joint disruption. At the time of this report's publication, the preventive use of clotting factor concentrates given at regular intervals had already been adopted for several decades in Sweden (Nilsson 1976). Then in 1994, the Medical and Scientific Advisory Council (MASAC), of the United States of America's National Hemophilia Foundation reviewed the Swedish experience with prophylaxis and issued guidelines stating that prophylaxis should be considered the optimal therapy for children with severe hemophilia A and B (NHF 1994).

In the meanwhile, the focus of managing an individual with hemophilia has changed from treating an acute bleeding episode to the comprehensive care of the individual, including the administration of clotting factor concentrate outside the hospital or treatment centre, as subsequently theorized and better defined (Teitel 2004).

In fact, the efficacy of prophylaxis is expected to be higher if started early, i.e. before the establishment of any degree of joint deterioration, and continued as much as possible, as only home care treatment allows.

In this perspective, currently agreed definitions of prophylaxis are those proposed by the European Paediatric Network for Haemophilia Management (Berntorp 2003; Ljiung 2000). In particular, prophylaxis was defined as:

- primary A (determined by age) if regular continuous treatment is started after the first joint bleed and before the age of two years;

- primary B (determined by first bleed) if regular continuous treatment is started before the age of two years without previous joint bleeds;

- secondary A if regular continuous (long-term) treatment is started after two or more joint bleeds or at an age of over two years;
- secondary B if intermittent regular (short-term) treatment is applied, based on frequent bleed events.

Primary prophylaxis (A or B) and secondary A regimens require at least three doses per week for 42 weeks per year.

Despite the above recommendations, prophylaxis has not been universally adopted because of medical, psychosocial, and cost controversies (Blanchette 2004). In fact, the use of clotting factor concentrates is the single largest predictor of overall cost in the care of people with hemophilia (Miners 2004; Miners 2009), and it prevents its extensive application worldwide. Furthermore, there is no general agreement on the optimal prophylaxis regimen, and some schemes differ from that proposed by the European Paediatric Network which has been recently proven to be feasible (Feldman 2006; Collins 2009). In addition, evidence is accumulating about the efficacy of secondary prophylaxis started in adulthood to slow the progression of hemophilic arthropathy in already damaged joints or to relieve symptoms, or both, and improve QoL (Fisher 2003; Hay 2007).

In order to help clarify the open issues and provide optimal treatment recommendations for as many people with hemophilia as possible, we aim to systematically appraise the available evidence for the effectiveness of prophylactic administration of factor concentrates

\section{O B JE C T I VES}

The objective of this review is to evaluate whether the preventive use of clotting factor concentrates in people with hemophilia A or $\mathrm{B}$ improves short- and long-term outcomes as measured by one or more of the following:

\section{Short-term}

1. number of bleeding episodes per year or bleeding frequency

2. clotting factor concentrate plasma levels

\section{Long-term}

1. clinical joint function

2. orthopedic joint score

3. radiologic joint score

4. QoL measurements

Clotting factor concentrates given to prevent bleeding and bleeding-related complications in people with hemophilia A or B (Review) 


\section{Criteria for considering studies for this review}

\section{Types of studies}

Randomised or quasi-randomised clinical trials. All identified trials, unpublished or published as an article, an abstract or a letter, without any language limitations, were eligible.

\section{Types of participants}

Children and adults with congenital hemophilia A or B, including all ages and all degrees of severity. People with factor VIII or IX inhibitors were excluded.

\section{Types of interventions}

Trials included were those where intravenous clotting factor concentrates were administered as prophylactic treatment in any formulation (fresh frozen plasma, cryoprecipitate, lyophilised plasma derived clotting factor concentrate, or recombinant clotting factor concentrate), any concentration, any frequency and any dose were compared with no treatment, or on-demand treatment, or with one or more different prophylaxis regimens. The duration of treatment was greater than a single treatment. At least one treatment had to be a clotting factor concentrate.

Therefore the comparison groups are as follows:

1. prophylaxis versus placebo;

2. prophylaxis versus on-demand treatment;

3. prophylaxis versus alternative prophylaxis.

\section{Types of outcome measures}

\section{Primary outcomes}

1. Number of bleeding episodes or bleeding frequency

\section{Secondary outcomes}

1. Pain scores

2. Radiologic joint score or radiologic measurements or descriptions of joint damage

3. Orthopedic joint score or clinical joint function

4. QoL

5. Clotting factor concentrate plasma levels

6. Time loss to school or employment

7. Integration into society

8. Scales recording feeling of well-being and global functioning

9. Cost effectiveness, cost benefit, cost utilization, cost minimization
10. Any reported adverse effects or toxicity of clotting factor concentrates will be recorded (e.g. inhibitors, reactions, transmission of infection)

\section{Search methods for identification of studies}

\section{Electronic searches}

Relevant trials were identified from the Group's Coagulopathies Trials Register using the term: prophylaxis and hemophilia* or haemophilia*.

The Coagulopathies Trials Register is compiled from electronic searches of the Cochrane Central Register of Controlled Trials (Clinical Trials) (updated each new issue of The Cochrane Library) and quarterly searches of MEDLINE and the prospective handsearching of one journal - Haemophilia. Unpublished work is identified by searching the abstract books of major conferences: the European Haematology Association conference; the American Society of Hematology conference; the British Society for Haematology Annual Scientific Meeting; and the Congress of the World Federation of Hemophilia. For full details of all searching activities for the register, please see the relevant section of the Cystic Fibrosis and Genetic Disorders Group Module.

Date of the most recent search of the Group's Coagulopathies Trials Register: 07 April 2011.

We performed additional searches on MEDLINE (from January 1966 to 14 February 2011), and EMBASE (from 1988 to 14 Feburary 2011) (both on the OVID platform) and CENTRAL (Issue 4, 2010). For the full search strategies, please refer to the appendices (Appendix 1; Appendix 2).

\section{Searching other resources}

The bibliographic references of all retrieved studies and reviews were assessed for additional reports of clinical trials. For the 2011 update, handsearching of the proceedings of the International Society for Thrombosis and Haemostasis bi-annual meeting and proceedings of the European Association for Haemophilia and Allied Disorders were performed for the years 2004 to 2010.

\section{Data collection and analysis}

\section{Selection of studies}

Two authors independently examined the titles and abstracts of trials generated from the database searches to identify potentially relevant studies. They retrieved complete manuscripts for all potentially relevant studies. With the full text manuscripts, the authors independently assessed the studies using a standardised form. 
They resolved differences, regarding which studies to include, by consensus reached after discussion.

\section{Data extraction and management}

Using a structured data form the authors extracted the following information: characteristics of the study; study participants' demographics; the study intervention and co-interventions (including doses of clotting factor concentrate); study outcomes (including primary and secondary outcomes). Two authors extracted data independently and compared the results. They resolved differences by consensus and referral to the original paper.

Authors considered outcome data if recorded as either individual events or as events grouped by time periods.

\section{Assessment of risk of bias in included studies}

The authors used the standard built-in tool in RevMan 5.1 to measure the risk of bias and to produce summary figures (RevMan 2011).

The authors assessed the risk of bias using the 'Risk of bias' assessment tool as documented in section 8.5 of the Cochrane Handbook for Systematic Reviews of Interventions (Higgins 2011). The following domains were assessed as having either a low, high or unclear risk of bias:

- sequence generation;

- allocation concealment;

- blinding (of participants, personnel and outcome assessors);

- incomplete outcome data;

- selective outcome reporting;

- other sources of bias.

Results of the risk of bias assessment are displayed in the risk of bias tables in the 'Characteristics of included studies' tables.

\section{Measures of treatment effect}

We expected rates of events to be the measures reported for the primary outcome. We expected rate of events or mean and standard deviations (SD) to be the measures reported for most of the secondary outcomes. Consequently, and taking also into account the high number of events expected for the primary outcome, the authors chose the rate difference as the measure of treatment effect for the primary outcome and risk difference or the mean difference (MD) for the secondary outcomes. The authors accounted for any deviation from this plan in the text.

\section{Unit of analysis issues}

Hemophilia lends itself to cross-over study design, as it is a chronic incurable genotypically-stable disease, and treatment with clotting factor concentrate has a rapid onset and short duration as the factor VIII and IX physiological half-lives are 12 and 24 hours respectively. Thus, we expected at least some of the studies to be cross- over in design. As a pre-planned analysis we stated that we would use the generic inverse variance (GIV) method when individual patient data were available or after obtaining the relevant data. If such data were available, we would have analysed any parallel group studies the same way to allow pooling of data. Otherwise, we used the standard RevMan method for parallel group trials (RevMan 2011).

\section{Dealing with missing data}

We contacted two authors to obtain additional data, but to date, none have been received (Gringeri 2011; Manco-Johnson 2007).

\section{Assessment of heterogeneity}

If we had included a sufficient number of studies in any metaanalysis, then we would have assessed clinical heterogeneity by visual and statistical analysis. For future updates, if we include a sufficient number of studies, we will use the $\mathrm{I}^{2}$ method to assess for heterogeneity in meta-analysis. If $\mathrm{I}^{2}$ is equal to or greater than $50 \%$ we will consider this indicative of heterogeneity. We have reported both $\mathrm{I}^{2}$ and Cochran Q chi -squared values.

\section{Assessment of reporting biases}

We planned to look for publication bias, checking open trial registries (www.clinicaltrials.gov) and using visual inspection of the funnel plot graph (if there were 10 or more included studies). Given the rarity of the disease and its chronic course, we believe publication bias is unlikely to occur since any similar trials would have been openly planned and run in the small hemophilia community. We investigated outcome reporting bias by looking for differences between trial reports and the original protocols or challenging any relevant unreported outcome data.

\section{Data synthesis}

Due to the low number of available studies, we have conducted the meta-analyses of the primary data using a random-effects model.

\section{Sensitivity analysis}

We undertook a post hoc sensitivity analysis for adverse events (central venous catheter (CVC) patients) (Analysis 2.6)

\section{RE S U L T S}

\section{Description of studies}

See: Characteristics of included studies; Characteristics of excluded studies. 


\section{Results of the search}

In the study search for the first edition of this systematic review, using the above search strategies, 890 unique references were identified. The authors assessed the titles and abstracts, from which 119 unique new articles were retrieved, 29 studies were considered for inclusion and 4 were finally included. One additional study was identified by contacting the primary author of an identified congress abstract. The original selection and extraction was performed by KS and AI.

Study selection and data extraction for the 2011 update were performed in duplicate by EM and MM. A total of 569 new references were retrieved, from which 82 unique references were identified by title and abstract scanning and 9 unique articles were identified as being potentially relevant. Three new references (to two studies) were finally included. Data about the'Joint Outcome Study (JOS)' were provided by two of these references (Manco-Johnson 2007), while data about the ESPRIT study were retrieved in one reference (Gringeri 2011). Additional details about these two studies were requested from the authors (Gringeri 2011; Manco-Johnson 2007). For the JOS study we requested additional details about inhibitors (distributions into the two treatment arms and inhibitor levels); the data were partially provided by dr Manco-Johnson.

\section{Included studies}

Six studies, with a total of 142 participants, were identified as being relevant and included in the data analysis (Aronstam 1976; Aronstam 1977; Carlsson 1997; Gringeri 2011; Manco-Johnson 2007; Morfini 1976). There was no disagreement between the two authors with respect to study relevance. The six studies were heterogeneous as each study used a different intervention. Given the available data, a meta-analyses could be performed for two studies (Gringeri 2011; Manco-Johnson 2007).

One study was performed in the USA (Manco-Johnson 2007) and five studies were conducted in Europe. Two studies were conducted in Italy (Gringeri 2011; Morfini 1976), one in Sweden (Carlsson 1997) and two in England (Aronstam 1976; Aronstam 1977). The four participants in the second English study had participated in the earlier one. There were approximately six months between the completion of the first study and the commencement of the second. All studies were published in English.

Two studies were randomised controlled open studies (Gringeri 2011; Manco-Johnson 2007). Four were cross-over in design ( Aronstam 1976; Aronstam 1977; Carlsson 1997; Morfini 1976), and all six used bleed frequency as the primary outcome measure. The interventions were not similar between the studies, leading to heterogeneous results and an inability to perform an overall metaanalysis. The two more recent studies allowed us to pool data for some of the outcomes (Gringeri 2011; Manco-Johnson 2007).

\section{Types of Participants}

The JOS study included patients on primary prophylaxis (MancoJohnson 2007); the ESPRIT study included patients in primary and secondary prophylaxis (Gringeri 2011); the remaining four trials reported data about secondary prophylaxis (Aronstam 1976; Aronstam 1977;.Carlsson 1997; Morfini 1976).

In one study the participants were people with severe hemophilia B (factor IX less than 1\%) (Morfini 1976). In three studies the participants were people with severe hemophilia A (factor VIII less than 1\%) (Aronstam 1976; Aronstam 1977; Gringeri 2011). One study included people with clinically severe hemophilia, where one participant had a pharmacological moderate level of factor VIII (1.5\%), but behaved clinically as a person with severe hemophilia A (Carlsson 1997). The JOS study included people with severe and moderate-severe hemophilia A with factor VIII level below than 2\% (Manco-Johnson 2007). The age range of participants was from 1 year to 45 years. All participants were male, and none had inhibitors. The studies varied in sample size with 9, 4, 14, 40, 65 and 10 participants respectively (Aronstam 1976; Aronstam 1977; Carlsson 1997; Gringeri 2011; Manco-Johnson 2007; Morfini 1976).

\section{Types of Interventions}

Four studies were cross-over in design (Aronstam 1976; Aronstam 1977; Carlsson 1997; Morfini 1976). The order of the intervention was randomised, and all participants received both the control and active treatment. Different interventions were used in the four studies. The treatment arm was either a larger amount (Aronstam 1976; Aronstam 1977 ) or a more frequent dosing schedule (Morfini 1976) of clotting factor concentrate than the control arm, or a modified prophylaxis dose of clotting factor concentrate based on individual pharmacokinetic data (Carlsson 1997). The control arm was either a non-physiologic effective dose of clotting factor concentrate (Aronstam 1976), a physiologic effective clotting factor concentrate dose (Aronstam 1977; Morfini 1976), or a standard prophylaxis schedule of clotting factor concentrate (Carlsson 1997). In the Carlsson study, upon enrolment in the clinical trial, each patient received a single standard dose of clotting factor concentrate (factor VIII 25 to $40 \mathrm{IU} / \mathrm{kg}$ ), and a pharmacokinetic evaluation was calculated by standard "modelindependent" procedures; the individual's pharmacokinetic data were used to fit computer-simulated multiple-dose activity curves of factor VIII for each case, to clinically achieve a factor VIII trough level above 1\% (Carlsson 1997).

One study compared a regimen of clotting factor concentrate to increase the factor VIII dose to $25 \%$ of the normal compared to $1 \%$ of the normal (Aronstam 1976). A second study compared bi-weekly dosing of clotting factor concentrate to raise factor VIII to $30 \%$ of normal, versus $15 \%$ of normal (Aronstam 1977). The study by Morfini compared the same total dose of factor IX clotting factor concentrate per week, administered either weekly (15 IU/kg) or bi-weekly (7.5 IU/kg) (Morfini 1976). The study by 
Carlsson compared standard dose prophylaxis (25 to $40 \mathrm{IU} / \mathrm{kg}$ / dose) given three times per week with the dose and interval based on individual pharmacokinetic data (Carlsson 1997). In all four studies, the clotting factor concentrate dosing interval allowed a physiological washout period of treatment effect before the crossover intervention was undertaken.

The two new studies at the 2011 update were open randomised controlled trials (Gringeri 2011; Manco-Johnson 2007).These studies compared a prophylaxis treatment group versus an on-demand treatment group. One study compared a prophylaxis group with a factor VIII infusion of $25 \mathrm{IU} / \mathrm{kg}$ of body weight every other day versus on-demand treatment with $40 \mathrm{IU} / \mathrm{kg}$ of body weight at the time of joint haemorrhage followed by 20 IU at 24 hours and 72 hours after the first dose (Manco-Johnson 2007). When hemarthroses occurred in the prophylaxis group, patients were treated with $40 \mathrm{IU} / \mathrm{kg}$ at the time of joint haemorrhage. The second trial compared prophylactic treatment with $25 \mathrm{IU} / \mathrm{kg}$ of body weight three-times weekly versus on-demand treatment with 25 IU/kg of body weight until complete healing (Gringeri 2011).

\section{Types of Outcomes}

The primary outcome of interest, bleeding events or bleed frequency, was reported in all six studies. All outcomes were standardized to event rates per year.

Range of motion of affected joints was collected in one study, but the data were collected at the completion of the study, after the participants had experienced both interventions in a cross-over fashion (Morfini 1976). Data about long-term joint deterioration and adverse events (inhibitors rate, and infection) were reported in two studies (Gringeri 2011; Manco-Johnson 2007).
A secondary outcome reported in one study was 'morbidity', and it was defined as "time spent in the college sick bay or at hospital, where more than three hours under medical care was noted as one day" (Aronstam 1976). A further secondary outcome that was reported in three studies was the quantity of clotting factor concentrate administered (Carlsson 1997; Gringeri 2011; MancoJohnson 2007). Quality of life data were reported in one study (Gringeri 2011).

\section{Excluded studies}

Thirty-one studies were excluded because they were not RCTs. We classified these as controlled observations and included them in an additional table because of their potential use in estimating the baseline risk and variability of treatment effect size in different populations (Table 1). Twenty-five studies were excluded after the first search, an additional reference to one of these studies was identified during a later search (Feldman 2006). Six other studies were excluded from the analysis at the 2011 update and details are presented in the additional tables (Collins 2010; Fischer 2005; Nemes 2007; Schobess 2008; Tagliaferri 2008; Wu 2011) (Table $1)$.

\section{Risk of bias in included studies}

An overall graphical representation of the risk of bias assessment is provided in the figures (Figure 1; Figure 2). It was noted in particular, in relation to blinding, the risk of bias was found to be high in two studies (Carlsson 1997; Morfini 1976). In relation to 'other potential sources of bias', one trial was assessed as having a high risk of bias due to a significant number of patients crossing over the allocated treatment arms (Gringeri 2011).

Figure I. Risk of bias graph: review authors' judgements about each risk of bias item presented as percentages across all included studies.

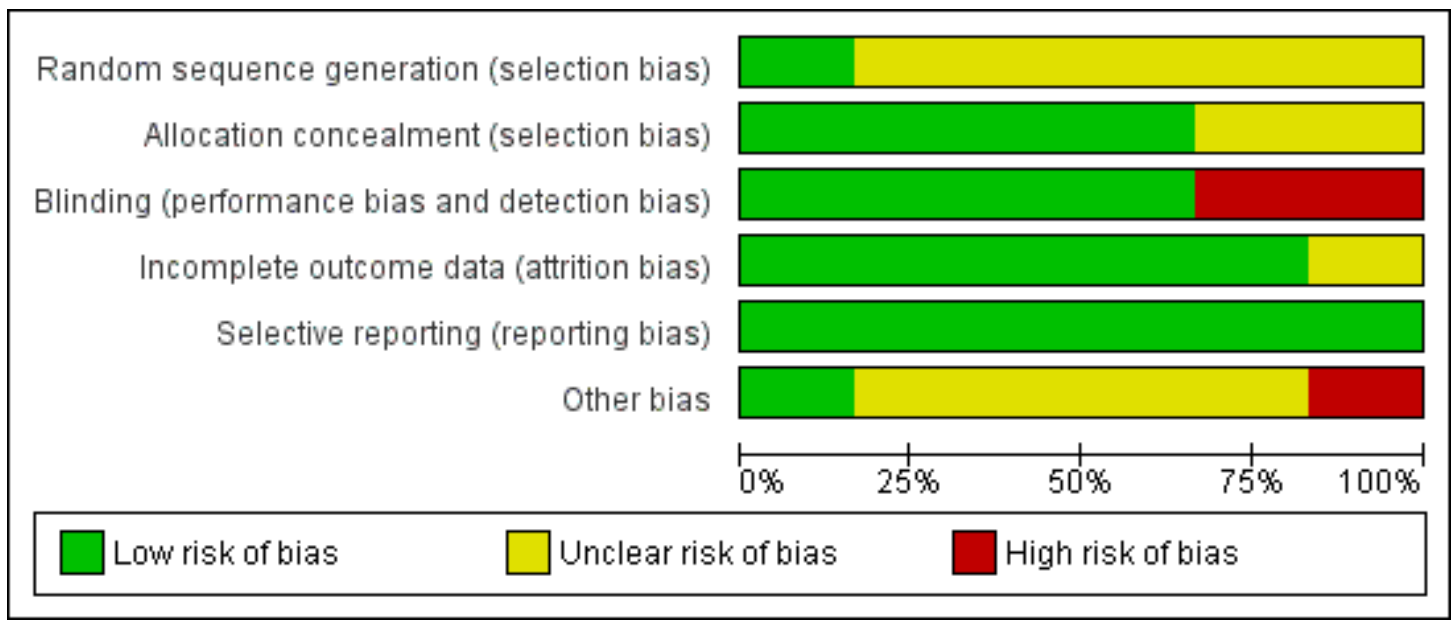

Clotting factor concentrates given to prevent bleeding and bleeding-related complications in people with hemophilia A or B (Review) 
Figure 2. Risk of bias summary: review authors' judgements about each risk of bias item for each included study.

\begin{tabular}{|c|c|c|c|c|c|c|}
\hline & 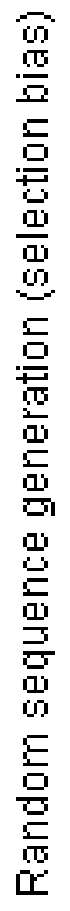 & 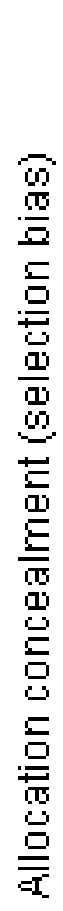 & 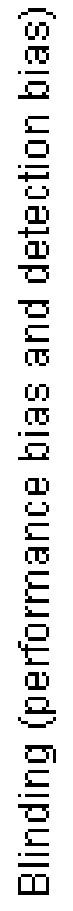 & 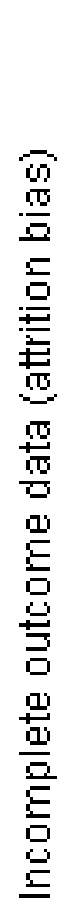 & 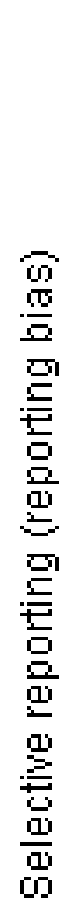 & 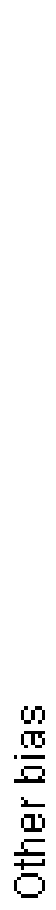 \\
\hline Aronstam 1976 & $?$ & + & 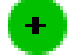 & & & $?$ \\
\hline Aronstam 1977 & $?$ & $?$ & & & & $?$ \\
\hline Carlsson 1997 & $?$ & $?$ & & & & $?$ \\
\hline Gringeri 2011 & + & & & & & \\
\hline Manco-Johnson 2007 & $?$ & & & & & \\
\hline Morfini 1976 & $?$ & + & & $?$ & + & $?$ \\
\hline
\end{tabular}




\section{Allocation}

All six studies were described as being randomised, but none reported details about sequence generation. Four studies were judged as having suitable concealment (Aronstam 1976; Gringeri 2011; Manco-Johnson 2007; Morfini 1976). In the remaining two studies there was no allocation concealment (Aronstam 1977; Carlsson 1997).

\section{Blinding}

One study described an appropriate method of double blinding, where the physicians administering the study treatment were in a different institution from the physicians evaluating and treating bleeding episodes (Aronstam 1977). Two studies stated that the patients were unaware of the treatment administered by the physician (Aronstam 1976; Aronstam 1977). The ESPRIT study had a blinded assessment of orthopedic and radiographic scores (Gringeri 2011). The JOS study had blinded assessment of orthopedic and radiographic scores and of laboratory assessments (Manco-Johnson 2007). The remaining trials were unblinded.

\section{Incomplete outcome data}

All six studies discussed withdrawals. Two studies had no withdrawals (Morfini 1976; Aronstam 1977). One study had two withdrawals, these were voluntary discontinuations by two participants who bled soon after a low dose administration (Aronstam 1976). The fourth trial had seven withdrawals (four withdrew their consent, three had an unpredictable pharmacokinetic modified dosage schedule) (Carlsson 1997). The ESPRIT study was analysed by intention-to-treat, and recorded 8 withdrawals ( 4 in each arm) (Gringeri 2011). The JOS study reported 5 (out of 32) withdrawals in the prophylaxis group and 11 (out of 33) (3 for life-threatening haemorrhages) in the on-demand group (Manco-Johnson 2007). This study was analysed by intention-to-treat.

\section{Selective reporting}

Selective reporting was assessed only for trials with registered protocols. The only protocol found was for the JOS trial, registered at the end of enrolment (September 2005) on www.clinicaltrials.gov (NCT00207597) (Manco-Johnson 2007). All the outcomes reported in the protocol were analysed in the published paper. The main outcome was identical in the protocol and the published paper. For the remaining studies we assessed correspondence between methods and results sections. It was difficult to judge the occurrence of non reporting of clinically relevant for the older trials included in the review.

\section{Other potential sources of bias}

It was reported in three studies that they were sponsored by pharmaceutical companies (Carlsson 1997; Gringeri 2011; Manco-
Johnson 2007). One study did not record sponsorship (Morfini 1976). Three studies received financial support from external sources (Aronstam 1976; Aronstam 1977; Carlsson 1997). A significant degree of cross-over between the two treatment arms was reported for ESPRIT trial (Gringeri 2011). The four studies designed as cross-over did not have a wash out period and did not take any other method to avoid or account for carry-over effect.

\section{Effects of interventions}

\section{Standard prophylaxis regimen compared to a placebo regimen}

One study was included in the comparison (Aronstam 1976). The characteristics of the included study were:

- Type of prophylaxis: secondary prophylaxis

- Age range: 13 years to 17 years old

- Follow-up duration: at least two school terms

- Number of enrolled patients: 9

\section{Primary outcome}

\section{Bleeding frequency}

The clinical trial found a statistically significant advantage for the higher dose of factor VIII as compared to a non-physiologic dose with a rate difference for bleeding frequency of -10.73 (95\% CI 16.55 to -4.91 ) bleeds per year (Analysis 1.1).

\section{Secondary Outcomes}

\section{Pain Scores}

This outcome was not reported.

\section{Radiologic joint score}

This outcome was not reported.

\section{Orthopedic joint score}

This outcome was not reported.

\section{QoL}

This outcome was not reported.

\section{Clotting factor concentrate levels}

This outcome was not reported. 


\section{Time loss to school or employment}

The study assessed morbidity, defined as "time spent in the college sick bay or at the hospital" (Analysis 1.2). The mean rate difference was statistically significant $(\mathrm{P}<0.05)$, favouring treatment of children on the high-dose regimen (factor VIII $0.25 \mathrm{IU} / \mathrm{kg}$ ), who spent less time confined to bed, rate difference $0.28(95 \%$ CI 0.20 to 0.40 ). In this trial individual participant data were not provided, and therefore a logarithmic rate difference was calculated (Deeks 2011).

\section{Integration into society}

This outcome was not reported.

\section{Well-being and global functioning}

This outcome was not reported.

\section{Cost effectiveness, cost benefit, cost utilization, cost minimization}

This outcome was not reported.

\section{Adverse events}

The study summarized adverse events or complications at the end of the study, after participants had received both the treatment and control interventions. However, no participant developed a factor VIII inhibitor or became hepatitis B surface antigen positive during the clinical trial (Aronstam 1976).

\section{Standard prophylaxis regimen compared to on- demand treatment}

Two studies were included in the comparison (Gringeri 2011; Manco-Johnson 2007). The characteristics of the include studies were:

Gringeri 2011

- Type of prophylaxis: secondary and primary prophylaxis .

- Age range: less than seven years old

- Follow-up duration: median 82.5 months (range: 2

months to 163 months)

- Number of enrolled patients: 40

Manco-Johnson 2007

- Type of prophylaxis: primary prophylaxis

- Age range: less than 30 months

- Follow-up duration: mean 49 months (range: 48 to 58 months)

- Number of enrolled patients: 65

\section{Primary outcome}

\section{Bleeding frequency}

The comparison showed a significant statistical reduction of total bleeding in patients treated on prophylaxis versus those treated on demand. The rate difference was calculated for the JOS study only (Manco-Johnson 2007), since the SD for the main effect was not reported for the ESPRIT study (because of skewed data distribution) and not provided by the authors upon request (Gringeri 2011). The rate difference for the JOS study was -14.42 (SD 7.91) for bleed frequency and -4.16 (SD 2.71) for joint bleeds. To provide a pooled estimate of the effect on bleeding rate, the rate ratio was used, rate ratio 0.30 (95\% CI 0.12 to 0.76$), \mathrm{I}^{2}$ 99\% $\left(\mathrm{Chi}^{2}\right.$ 196.78, P < 0.00001) (Analysis 2.1). A similar significant reduction was found when pooling results for joint bleeding, rate ratio 0.22 (95\% CI 0.08 to 0.63), $\mathrm{I}^{2}$ 98\% ( $\mathrm{Chi}^{2}$ 63.31, P < 0.00001) (Analysis 2.2). The pooled estimates should be considered with caution due to the very high level of heterogeneity, very likely due to the different characteristics of the population in the two studies. The absolute bleeding rates in the control groups were for all bleedings $17.7+/-9.2$ (events per patient per year, mean and SD) in the JOS study and 0.48 (events per patient per month, mean) in the ESPRIT study; for joint bleedings $4.9+/-3.6$ (events per patient per year, mean and SD) in the JOS study and 0.24 (events per patient per month) in the ESPRIT study for joint bleeds.

\section{Secondary Outcomes}

\section{Pain Scores}

This outcome was not reported.

\section{Radiologic joint score}

We did not pool the data for this outcome due to two additional causes of variability in the two studies (duration of follow-up and the intensity of treatment in the control group (enhanced on-demand prophylaxis in the JOS study)). Only patients on primary prophylaxis in the ESPRIT study showed a statistically significant protection from joint damage with prophylaxis when this was compared to standard on-demand treatment (risk difference 0.70 (95\% CI 0.39 to 1.01 ) while the difference in the JOS study was borderline significant, risk difference 0.15 (95\% CI -0.01 to 0.31) (Analysis 2.3). The effectiveness of secondary prophylaxis was tested in the ESPRIT study only, resulting in a non-significant difference, risk difference for reduction in the progression of radiologic evidence of joint damage 0.32 (95\% CI -0.07 to 0.70 ) (Analysis 2.3). 


\section{Orthopedic joint score}

This outcome was not reported.

\section{QoL}

Only the ESPRIT trial reported data on QoL (Gringeri 2011). The Haemo-QoL questionnaire showed that overall QoL was of 22.2 (SD 8.2), in a scale from 0 to 100 , where 100 indicates completely deteriorated QoL. When assessing the impact of treatment, a significant difference was found in children receiving ondemand treatment versus those receiving prophylaxis in the subscale exploring the dimension "family", which was more impaired in the on-demand treatment group, MD 32.73 (95\% CI 22.30 to 43.16) (Analysis 2.4).

\section{Clotting factor concentrate usage}

The studies showed a significant increased consumption of factor VIII in the patients treated with prophylaxis as compared to those treated on demand. Monthly factor usage per patient on the ESPRIT trial was 8852 IU and 3981 IU in the prophylaxis group and in the on-demand group, respectively (Gringeri 2011) and in the JOS study they were 5880 IU and 1887 IU per patient per month in the prophylaxis group and in the on-demand group respectively, MD $5270 \mathrm{IU} /$ month per patient (95\% CI 4230 to 6320), $\mathrm{I}^{2}$ 0\% $\left(\mathrm{Chi}^{2}\right.$ 0.24, $\mathrm{P}=0.62$ ) (Analysis 2.5).

\section{Time loss to school or employment.}

The outcome was not reported.

\section{Integration into society}

The outcome was not reported.

\section{Well-being and global functioning}

The outcome was not reported.

\section{Cost effectiveness, cost benefit, cost utilization, cost minimization}

In the ESPRIT study a cost analysis was performed (Gringeri 2011). Cost evaluation was based on the annual FVIII consumption. A societal perspective was adopted (third party payer, i.e. the Italian National Health Service), and all the health care resources absorbed by the care of patients were specifically considered. With an average price per IU of recombinant factor VIII concentrates of EUR 0.75, the cost for one year of prophylaxis was EUR 79,668 compared to EUR 35,829 for one year on on-demand therapy. The incremental cost-efficacy ratio per bleeding events avoided in patients on prophylaxis was EUR 7537. The incremental costefficacy ratio for maintaining all joints unaffected over the whole treatment period was EUR 201,601.12.

\section{Adverse events}

Both studies reported the rate of infections per treatment group. When all the enrolled patients were considered, a non-significant difference against prophylaxis was observed, risk difference 0.14 (95\% CI -0.14 to 0.42 ), $\mathrm{I}^{2} 75 \%\left(\mathrm{Chi}^{2} 4.04, \mathrm{P}=0.04\right.$ ) (Analysis 2.6). Analysis of the inhibitor rate was complicated by suboptimal reporting of inhibitor incidence in both studies. In the Gringeri study, the incidence of inhibitors was reported without providing the distribution in high or low-responding/transient inhibitors (Gringeri 2011). In the JOS study, the assignment to treatment group of seven low-responding/transient inhibitors was not provided (Manco-Johnson 2007). Both authors were contacted to obtain additional data, but to date, none have been received. When compared using the data as reported in the publications, the inhibitor rate was not significantly higher in patients on prophylaxis, risk difference 0.06 (95\% CI -0.03 to 0.15$) \mathrm{I}^{2} 0 \%\left(\mathrm{Chi}^{2} 0.06, \mathrm{P}\right.$ $=0.81$ ) (Analysis 2.6).

\section{Adverse events in central venous catheter (CVC) patients (sensitivity analysis)}

Since both infections and inhibitor development are reported to be more common in patients with CVC, we also analysed adverse events in this subgroup of patients. Data allowing the comparison were available from the JOS study only (Manco-Johnson 2007), since in the ESPRIT study only patients on prophylaxis had CVC placed (6 out of 10) (Gringeri 2011), and no infection or incidence of inhibitors were recorded in patients without a central vein access. A non-significant difference was observed, risk difference 0.03 (95\% CI -0.26 to 0.19 ) (Analysis 2.6). In a further sensitivity analysis, we calculated the number of patients with CVC and events in the two studies $(6 / 10$ additional patients in the ESPRIT prophylaxis group), ending with $12 / 39$ and $6 / 25$ infections during prophylaxis or on-demand treatment in CVC patients, respectively, and recalculated an unadjusted risk difference of 0.07 (95\% CI -0.15 to 0.29 ). Similarly for inhibitor rate we found a non-significant excess of inhibitors in CVC patients on prophylaxis versus those on demand ( 1 out of 29 versus 1 out of 25 , respectively with a risk difference of -0.01 (95\% CI -0.11 to 0.10$)$ ) (Analysis 2.6), unadjusted risk difference 0.06 (95\% CI -0.06 to 0.18 ).

\section{Standard prophylaxis regimen compared to an alternative prophylaxis regimen}

Three studies were included in this comparison but could not be aggregated as one study compared bi-weekly dosing of clotting factor concentrate given at a dose to raise factor VIII to $30 \%$ of normal, versus a dose to get $15 \%$ of normal factor VIII concentrate post-infusion level (Aronstam 1977), a second study was on people with hemophilia B (Morfini 1976), and the third compared standard dose prophylaxis ( 25 to $40 \mathrm{IU} / \mathrm{kg} / \mathrm{dose}$ ) given three times 
per week with a regimen in which the dose and interval were based on individual pharmacokinetic data (Carlsson 1997) .

The characteristics of the include studies were:

Aronstam 1977

- Type of prophylaxis: secondary prophylaxis

- Age range: 13 years to 17 years old

- Follow-up duration: at least two school term

- Number of enrolled patients: 4

Carlsson 1997

- Kind of prophylaxis: secondary prophylaxis

- Age range: 8 years to 42 years old

- Follow-up duration: one year

- Number of enrolled patients: 21 (14 included in the analysis)

Morfini 1976

- Kind of prophylaxis: secondary prophylaxis

- Age range: 5 years to 45 years old

- Follow-up duration: one year

- Number of enrolled patients: 10

\section{Primary outcome}

\section{Bleeding frequency}

Two studies did not find a statistical significant effect in the bleeding frequency: rate difference of -5.04 (95\% CI -17.02 to 6.94$)$ bleeds per year when comparing two different dosages (Aronstam 1977) (Analysis 3.1); and rate difference -0.14 (95\%CI -1.34 to 1.05) bleeds per year when assessing a PK-based regimen (Carlsson 1997) (Analysis 4.1). The Morfini study showed a significant difference in favour of the bi-weekly versus the once weekly dosing group, rate difference of -3.30 (95\% CI -5.50 to -1.10$)$ bleeds per year (Morfini 1976) (Analysis 5.1).

Note: as the dosage and frequency of administration of the clotting factor concentrate was different in the three studies, it was not possible to combine the studies.

\section{Secondary Outcomes}

\section{Pain Scores}

No studies reported this outcome.

\section{Radiologic joint score}

The radiological assessments in people with factor IX deficiency were made at the completion of the study, not at the completion of the separate interventions. Therefore, it was not possible to attribute effectiveness of the treatment intervention in this crossover design study (Morfini 1976).

\section{Orthopedic joint score}

The clinical orthopedic evaluations in people with factor IX deficiency were collected at the completion of the study, not at the completion of the separate interventions. Therefore, it was not possible to attribute effectiveness of the treatment intervention in this cross-over design study (Morfini 1976).

\section{Quality of life}

This outcome was not reported.

\section{Clotting factor concentrate levels}

One study reported clotting factor concentrate usage (Carlsson 1997). There was a significant difference in favour of the pharmacokinetic-optimised dosing group, mean difference of -3300 IU per month (95\%CI -1420 to -5180) (Analysis 4.2).

\section{Time loss to school or employment}

This outcome was not reported.

\section{Integration into society}

This outcome was not reported.

\section{Well-being and global functioning}

This outcome was not reported.

\section{Cost effectiveness, cost benefit, cost utilization, cost minimization}

One study reported savings with a PK-based regimen as compared to a standard prophylaxis regimen (Carlsson 1997). Savings for 14 patients over 6 months were USD 418,000 or GBP 270 (as calculated in 1997).

\section{Adverse events}

Two studies summarized adverse events or complications at the end of the study, after participants had received both the treatment and control interventions. The development of factor VIII inhibitors or positivity to hepatitis B surface antigen was collected at the completion of the study, but no participants developed an inhibitor or became newly hepatitis B surface antigen positive (Aronstam 1977; Morfini 1976).

\section{DISCUSSION}

This systematic review included six studies with a total of 142 participants with a different degree of arthropathy at baseline and 
variable types of interventions, which allowed only partial aggregation of data for clotting factor concentrate usage for the prevention of bleeding in people with hemophilia. On the whole, these studies provided evidence that prophylactic administration of clotting factor concentrates is effective in significantly preventing or slowing down the progression of hemophilic arthropathy. As a caveat, performing primary prophylaxis (i.e. started before a significant number of bleeds has occurred) in small children often requires clinicians to implant a venous access device. The use of these devices is complicated by local infection in a significant number of cases. Similarly, patients on prophylaxis in these studies developed more inhibitors than those receiving on-demand therapy, although the difference was not statistically significant and potentially associated with venous access implants or infection rather than to the prophylactic regimen.

The clinical management of people with hemophilia has changed over the past three decades, i.e. since the oldest clinical studies included in this review were undertaken. Hemophilia care is now provided under a comprehensive health care model and with prophylactic or on-demand treatment for the majority of bleeds given at home, i.e. outside the treatment centre.

The dates of publication of the earlier studies and the events that have occurred in the intervening years is worthy of comment. Three of the included studies were performed as early as the 1970s. Subsequently, the unfortunate events of the blood-borne infectious disease epidemic precluded the design and implementation of well-designed clinical trials in the 1980s. Later on, the introduction of recombinant human clotting factor concentrates removed any residual risk of infection. However, the ability to undertake a RCT on the effectiveness of prophylaxis was overshadowed by more than 20 years experience of primary prophylaxis with clotting factor concentrate compared to historical controls (Nilsson 1992; Petrini 1991; Brackmann 1992; Manco-Johnson 1994; van den Berg 2002). Although not RCTs, the observational studies indicated clear benefits in the reduction of bleed frequency and joint deformity. It has therefore been very difficult for investigators to decide if there was true equipoise in the choice between prophylactic and on-demand treatment. Essentially, coupled with this established pattern of practice, there are 30 unique observational studies reporting data from 1960 people with hemophilia undergoing clotting factor concentrate prophylaxis in comparison with 1312 people with hemophilia treated on-demand. Detailed characteristics of these observational studies are listed in an additional table (Table 1). These non-RCT observational studies have been used by healthcare providers to justify the use of clotting factor concentrate in primary prophylaxis in several countries throughout the world. Finally, and notwithstanding all the evidence above, two independent groups in the USA (Manco-Johnson 2007) and Italy (Gringeri 2011) found it ethically and scientifically sound to compare the widely-used thrice-a-week prophylaxis regimen with on-demand treatment. Both groups confirmed the superiority of administering prophylactic factor concentrates, by showing a reduction in the bleeding rate and progression of arthropathy. Both studies, however, demonstrated that hemophilia patients develop some degree of joint deterioration even when receiving prophylaxis. Furthermore, prophylaxis was found to be associated with a significant increase in the amount of resources used.

Why were the results of these two more recently performed studies positive and at variance with the four older studies? Bleeding episodes within and between people with hemophilia can vary considerably over a period of months. Furthermore, the pathologic process which leads to hemophilic arthropathy requires several years to produce clinically evident modifications in the affected joints. Only the two more recent of the six studies observed patients for 10 years (Gringeri 2011) and 4 years (Manco-Johnson 2007), time-spans that can be considered long enough to establish a significant difference. Of the remaining four studies included in the analysis, two observed participants for one year, and two for two or four "English school" terms. The bleeding frequency period studied may have been too short to be clinically meaningful, and the cross-over design could have been suboptimal in assessing differences in the setting of chronic disease, where information about effectiveness and optimal duration of the washout period are largely unknown. Carryover effect from on-demand treatment to prophylaxis might have negatively biased the effect of prophylaxis, while carryover from prophylaxis to on-demand treatment may have positively inflated the effectiveness of on-demand treatment. Furthermore, it has been repeatedly shown that prophylaxis exerts its effect mostly in patients whose joints are still unaffected joints (i.e. after one or at maximum two clinically relevant bleeding episodes). Most of the participants in the older studies had already presented with some degree of hemophilic arthropathy (Aronstam 1976; Aronstam 1977; Carlsson 1997; Morfini 1976), while the patients in the JOS study (Manco-Johnson 2007) and some of those in the ESPRIT study (Gringeri 2011) qualified to be considered as receiving primary prophylaxis. Of note, even the two more recent studies, though focused on prophylaxis in children, presented a high degree of heterogeneity, most likely due to the difference in either the characteristics of the population included or the different treatment scheme used for the on-demand control group (Gringeri 2011, Manco-Johnson 2007). Thus, the overall estimates of the meta-analyses should be considered with caution, and it may even have been inappropriate to pool the results of the two studies to give a point estimate. In addition to the estimate of the mean effect size, it is important that the clinical reader, when estimating the reduction in the bleeding frequency expected for a given patient, considers the appropriate value in the range of the confidence intervals, assuming that the baseline risk and the reduction are likely to be inversely correlated with the age and joint deterioration of the patient. The heterogeneity between the studies is most evident when considering the longterm effect of prophylaxis. In fact, only patients on primary prophylaxis in the ESPRIT study, where the control was standard on- 
demand treatment, showed a statistically significant protection of the joint function, while the difference in the JOS study, where enhanced prophylaxis was used as a comparator and the followup was shorter, was borderline significant (Analysis 2.3).

Prophylaxis has already been set as a standard in the western world, but there is still a lack of knowledge about several aspects of this treatment, as highlighted by the many outcomes that are considered relevant by hemophilia clinicians (and thus listed among the outcomes of interest for this review), but which have not been addressed or reported on by most of the studies. Furthermore, new randomised comparisons between different regimens to deliver prophylaxis are to be expected in the near future. In fact, during the course of the recent randomised studies and after their completion, several new issues about prophylaxis in hemophilia were raised, such as: optimal regimen (including both dose, frequency, individual tailoring by means of escalating-dose protocol or PK modelling); optimal starting point and regimen to preserve joint function and minimize inhibitor development (Kurnik 2010); whether or not to continue beyond childhood and the role of secondary prophylaxis in adult patients, etc. Similarly, several pharmacoeconomic evaluations have been published (Collins 2009; Miners 2009). Some of these studies have had a strong impact on the hemophilia community, and are likely to change the clinical practice in the western world. In low- and middle-income countries, studies are ongoing to evaluate the effectiveness of lowdose prophylaxis regimens.

\section{AUTHORS' CONCLUSIONS}

\section{Implications for practice}

There is evidence from RCTs and observational studies that the use of prophylactic clotting factor concentrate is effective in decreasing the frequency of joint bleeds and in partially preventing or slowing down the development of arthropathy.

\section{Implications for research}

Future randomised clinical trials should address the following aspects:

1. comparative efficacy, safety and effectiveness of different prophylactic regimens (escalating versus fixed-dose, pharmacokinetic-tailored versus fixed-dose);

2. optimal starting and ending age;

3. standardized clinical and radiological outcome measures of efficacy;

4. long-term cost-effectiveness.

\section{ACKNOWLEDGEMENTS}

The authors would like to thank Ellen Crumley MLIS, for her literature searching and medical librarian support and Natasha Wiebe MSc, for her statistical support.

We would like to thank John K. Wu for his contribution to the original protocol.

The authors would also thank Louis Aledort, Mike Makris, Pier Mannuccio Mannucci, Claude Negrier for their helpful comments on draft versions of this review.

We are indebted to Kerry Dwan for repeatedly reading our review, providing statistical advice, checking most of our calculations, solving doubts and ultimately sensibly improving this systematic review.

\section{R E F E R E N C E S}

\section{References to studies included in this review}

Aronstam 1976 \{published data only\}

Aronstam A, Arblaster PG, Rainsford SG, Turk P, Slattery

M, Alderson MR, et al.Prophylaxis in hemophilia: a double-

blind controlled trial. British Journal of Haematology 1976;

33(1):81-90. [MEDLINE: 76184531; : 50]

Aronstam 1977 \{published data only\}

Aronstam A, Kirk PJ, McHardy J, Culver-James JW,

McLEllan DS, Turk P, et al.Twice weekly prophylactic

therapy in haemophilia A. Journal of Clinical Pathology

1977;30(1):65-7. [: 117 (?112)]

Carlsson 1997 \{published data only\}

Carlsson M, Berntorp E, Björkman S, Lethagen S, Ljung

R. Improved cost-effectiveness by pharmacokinetic dosing of factor VIIII in prophylactic treatment of haemophilia A. Haemophilia 1997;3:96-101. [: 64]

Gringeri 2011 \{published data only\}

Gringeri A, Lundin B, von Mackensen S, Mantovani LG, Mannucci PM and the ESPRIT study Group. A Randomized Clinical Trial of Prophylaxis in Children with Hemophilia A (the ESPRIT Study). Journal of Thrombosis and Haemostasis 2011;9(4):700-10. [DOI: 10.1111/ j.1538-7836.2011.04214.x]

Manco-Johnson 2007 \{published data only\} Hacker MR, Page JH, Shapiro AD, Rich-Edwards JW, Manco-Johnson MJ. Central venous access device infections in children with hemophilia. Journal of Pediatric Hematology/Oncology 2007;29(7):458-64.

* Manco-Johnson MJ, Abshire TC, Shapiro AD, Riske B, 
Hacker MR, Kilcoyne R, et al.Prophylaxis versus episodic treatment to prevent joint disease in boys with severe hemophilia. New England Journal of Medicine 2007;357(6): $535-44$.

\section{Morfini 1976 \{published data only\}}

Morfini M, Mannucci PM, Mariani G, Panicucci F, Petrucci F, Baicchi U, et al.Evaluation of prophylactic replacement therapy in haemophilia B. Scandinavian Journal of Haematology 1976;16(1):41-7. [MEDLINE: 76129390; : 3]

\section{References to studies excluded from this review}

Aledort 1994 \{published data only\}

Aledort LM, Haschmeyer RH, Pettersson H, The orthopaedic outcome study group. A longitudinal study of orthopaedic outcomes for severe factor VIII deficient haemophiliacs. Journal of Internal Medicine 1994;236(4): 391-9.

Astermark 1999 \{published data only\} Astermark J, Petrini P, Tengbrorn L, Schulman S, Ljung $\mathrm{R}$, Berntorp E. Primary prophylaxis in severe haemophilia should be started at an early age but can be individualized. British Journal of Haematology 1999;105(4):1109-13.

Brackmann 1992 \{published data only\} Brackmann HH, Eickhoff HJ, Oldenburg J, Hammerstein U. Long-term therapy and on-demand treatment of children and adolescents with severe haemophilia A: 12 years of experience. Haemostasis 1992;22(5):251-8.

Chuansumrit 1995 \{published data only\} Chuansumrit A, Hathirat I, Hathirat P. Prophylactic treatment for haemophilia A patients:a pilot study. Southeast Asian Journal of Tropical Medicine of Public Health 1995;26 (2):243-6

Collins 2010 \{published data only\}

Collins P, Faradji A, Morfini M, Enriquez MM, Schwarz L. Efficacy and safety of secondary prophylactic vs. ondemand sucrose-formulated recombinant factor VIII treatment in adults with severe hemophilia A: results from a 13-month crossover study. Journal of Thrombosis and Haemostasis 2010;8(1):83-9.

Courter 2001 \{published data only\}

Courter SG, Bedrosian CL. Clinical evaluation of B-domain deleted recombinant factor VIII in previously untreated patients. Seminars in Hematology 2001;38(2):52-9.

Dzinaj 1996 \{published data only\} Dzinaj T, Funk M, Schimdt H, Bottger S, Gngor T, Klarmann D, et al.Radiological score in paediatric haemophilic patients with early and late onset of factor VIIIprophylaxis. Thrombosis Haemostasis 1996;76(4):630-1.

Feldman 2006 \{published data only\} Feldman BM, Pai M, Rivard GE, Israels S, Poon MC, Demers C, et al.Tailored prophylaxis in severe hemophilia A: interim results from the first 5 years of the Canadian Hemophilia Primary Prophylaxis Study. Journal of Thrombosis and Haemostasis 2006;4(6):1228-36.
Fischer 2005 \{published data only\}

Fischer K, Van Dijk K, Van Den Berg HM. Late prophylaxis for severe hemophilia: effects of prophylaxis started in adulthood [abstract]. Journal of Thrombosis and Haemostasis 2005;3(Suppl 1):OR205.

Kavakli 1997 \{published data only\} Kavakli K, Nisli G, Aydinok Y, Oztop S, Cetingul N, Aydogdu S. Prophylactic therapy for hemophilia in a developing country, Turkey. Pediatric Hematology and Oncology 1997;14(2):151-9.

\section{Kreuz 1998 \{published data only\}}

Kreuz W, Escuriola-Ettinghausen C, Funk M, Schmidt $\mathrm{H}$, Kornhuber B. When should prophylactic treatment in patients with haemophilia A and B start?- The German experience. Haemophilia 1998;4(4):413-7.

\section{Liesner 1996 \{published data only\}} Liesner RJ, Khair K, Hann IM. The impact of prophylactic treatment in children with severe haemophilia. British Journal of Haematology 1996;92(4):973-8.

Lofqvist 1997 \{published data only\} Löfqvist T, Nilsson IM, Berntorp E, Pettersson H. Haemophilia prophylaxis in young patients - a long-term follow-up. Journal of Internal Medicine 1997;241(5): 395-400.

Manco-Johnson 1994 \{published data only\} Manco-Johnson MJ, Nuss R, Geraghty S, Funk S, Kilcoyne R. Results of secondary prophylaxis in children with severe hemophilia. American Journal of Hematology 1994;47(2): 113-7.

Nemes 2007 \{published data only\} Nemes L, Lissitchkov T, Klukowska A, Dobaczewski G, Komrska V, Aureswald G, et al.Evaluation of pharmacokinetics, efficacy and safety of Immunate solvent detergent in previously treated patients with severe haemophilia A. Haemophilia 2007;13:9-11.

Nilsson 1970 \{published data only\} Nilsson IM, Blomback M, Ahlberg A. Our experience in Sweden with prophylaxis on haemophilia. Bibliotheca Hematologica 1970;34:111-24.

Nilsson 1976 \{published data only\} Nilsson IM, Hedner U, Ahlberg A. Hemophilia prophylaxis in Sweden. Acta Paediatrica Scandinavica 1976;65(2): $129-35$.

Nilsson 1992 \{published data only\} Nilsson IM, Berntorp E, Löfqvist T, Pettersson H. Twentyfive years experience of prophylactic treatment in severe haemophilia A and B. Journal of Internal Medicine 1992; 232(1):25-32.

Petrini 1991 \{published data only\} Petrini P, Lindvall N, Egberg N, Blomback M. Prophylaxis with factor concentrates in preventing hemophilic arthropathy. American Journal of Pediatric Hematology/ Oncology 1991;13(3):280-7. 
Petrini 2001 \{published data only\}

Petrini P. What factors should influence the dosage and interval of prophylactic treatment in patients with severe haemophilia A and B?. Haemophilia 2001;7(1):99-102.

Pettersson 1981 \{published data only\} Pettersson H, Nilsson IM, Hedner U, Norehn K, Ahlberg A. Radiologic evaluation of prophylaxis in severe haemophilia. Acta Paediatric of Scandinavia 1981;70(4):565-70.

Ramsay 1973 \{published data only\}

* Ramsay DM, Parker AC. A trial of prophylactic replacement therapy in haemophilia and Christmas disease. Journal of Clinical Pathology 1973;26(4):243-7.

Royal 2002 \{published data only\}

Royal S, Schramm W, Berntorp E, Giangrande P, Gringeri A, Ludlam C, et al.Quality-of-life differences between prophylactic and on-demand factor replacement therapy in European haemophilia patients. Haemophilia 2002;8(1): $44-50$.

Schimpf 1977 \{published data only\}

Schimpf KI, Fisher B, Rothmann P. Hemophilia A prophylaxis with factor VIII concentrate in a hometreatment program: a controlled study. Scandinavian Journal of Haematology. Supplementum 1977;30:1979-80.

Schobess 2008 \{published data only\}

Schobess R, Kurnik K, Friedrichs F, Halimeh S, Krümpel A, Bildingmaier $\mathrm{C}$. Effect of primary and secondary prophylaxis on the clinical expression of joint damage in children with severe haemophilia A. Thrombosis and Haemostasis 2008;99(1):71-6.

Smith 1996 \{published data only\} Smith PS, Teutsch SM, Shaffer PA, Rolka H, Evatt B. Episodic versus prophylactic infusions for hemophilia A: a cost-effectiveness analysis. Journal of Pediatrics 1996;129 (3):424-31.

Szucs 1996 \{published data only\}

Szucs TD, Öffner A, Schramm W. Socioeconomic impact of haemophilia care: results of a pilot study. Haemophilia 1996;2(4):211-7.

Tagliaferri 2008 \{published data only\}

Tagliaferri A, Franchini M, Coppola A, Rivolta GF, Santoro C, Rossetti G, et al.Effect of secondary prophylaxis started in adult and haemophiliacs. Haemophilia 2008;14(5): $945-51$.

Tusell 2002 \{published data only\}

Tusell J, Perez-Bianco R. Prophylaxis in developed and in emerging countries. Haemophilia 2002;8(3):183-8.

Van den Berg 2001 \{published data only\}

Van den Berg HM, Fisher K, Mauser-Bunschoten EP, Beek FJ, Roosendaal G, van der Bom JG, et al.Longterm outcome of individualized prophylactic treatment of children with severe haemophilia. British Journal of Haematology 2001;112(3):561-5.

Wu 2011 \{published data only\}

Wu R, Luke KH, Poon M, Wu X, Zhang N, Zhao L, Su J, Zhang J. Low dose secondary prophylaxis reduces joint and severe bleeding in severe and moderate hemophilia children: A pilot study in China. Haemophilia 2011;17(1):70-4.

\section{Additional references}

\section{Ahlberg 1965}

Ahlberg A. Haemophilia in Sweden VII. Incidence, treatment and prophylaxis of arthropathy and other musculoskeletal manifestations of haemophilia A and B. Acta Orthopedic Scandinavian 1965;77(Suppl 1):7-80.

\section{Berntorp 2003}

Berntorp E, Astermark J, Bjorkman S, Blanchette VS, Fisher K, Giangrande PL, et al.Consensus perspectives in prophylactic therapy for haemophilia: summary statement. Haemophilia 2000;9(Suppl 1):1-4.

Blanchette 2004

Blanchette VS, Manco-Johnson M, Santagostino E, Ljung R. Optimizing factor prophylaxis for the haemophilia population: where do we stand?. Haemophilia 2004;10 (Suppl 4):97-104.

Collins 2009

Collins PW, Bjorkman S, Fisher K, Blanchette V, Schroth P, Fritsch $S$, et al.Factor VIII requirement to maintain a target plasma level in the prophylactic treatment of severe hemophilia A: influences of variance in pharmacokinetics and treatment regimens. Journal of Thrombosis and Haemostasis 2009;8(2):269-75.

Deeks 2011

Deeks J, Higgins J, Altman D. Chapter 9 Analysing data and undertaking meta-analysis. In: Higgins JPT, Green $S$ (editors). Cochrane Handbook for Systematic Reviews of Interventions Version 5.1.0 [updated March 2011]. The Cochrane Collaboration, 2011. Available from www.cochrane-handbook.org.

Fisher 2003

Fisher K, Van Den Berg M. Prophylaxis for severe haemophilia:clinical and economical issues. Haemophilia 2003;9(4):376-81.

Hay 2007

Hay CR. Prophylaxis in adults with haemophilia. Haemophilia 2007;13(Suppl 2):10-5.

Higgins 2011

Higgins JPT, Altman DG. Assessing risk of bias in included studies. In: Higgins JPT, Green S editor(s). Cochrane Handbook for Systematic Reviews of Interventions. Version 5.1.0. Wiley-Blackwell, [updated March 2011]:187-242.

\section{Hilgartner 1974}

Hilgartner MW. Hemophilic arthropathy. Advances in Pediatrics 1974;21:139.

\section{Kurnik 2010}

Kurnik K, Bidlingmaier C, Engl W, Chehadeh H, Reipert B, Auerswald G. New early prophylaxis regimen that avoids immunological danger signals can reduceFVIII inhibitor development. Haemophilia 2010;16(2):256-62. 


\section{Ljiung 2000}

Ljiung R, Aranis-Vournas S, Kurnik-Auberger K, Van den Berg M, Chambost H, Claeyssens S. Treatment of children with haemophilia in Europe: a survey of 20 centres in 16 countries. Haemophilia 2000;6(6):619-24.

\section{Lusher 1997}

Lusher JM. Prophylaxis in children with hemophilia: is it the optimal treatment?. Thrombosis Haemostasis 1997;78 (1):726-9.

\section{MASAC}

National Hemophilia Foundation. MASAC. MASAC recommendation concerning prophylaxis (regular administration of clotting factor concentrate to prevent bleeding). www.hemophilia.org/NHFWeb/MainPgs/ MainNHF.aspx?menuid=57\&contentid=582 $($ accessed 01 July 2010), issue Document 107.

\section{Miners 2004}

Miners A, Lee CA. Setting research priorities to improve cost-effectiveness estimations of primary prophylaxis with clotting factor for people with severe haemophilia A. Haemophilia 2004;10(Suppl 1):58-62.

\section{Miners 2009}

Miners A. Revisiting the cost-effectiveness of primary prophylaxis with clotting factor for the treatment of severe haemophilia A. Haemophilia 2009;15(4):881-7.

\section{NHF 1994}

The National Hemophilia Foundation. Medical and Scientific Advisory Council recommendations concerning prophylaxis [abstract]. Medical Bulletin. New York, 1994; Vol. No.193, Chapter Advisory No.197.

\section{RevMan 2011}

The Nordic Cochrane Centre, The Cochrane Collaboration. Review Manager (RevMan). 5.1. Copenhagen: The Nordic Cochrane Centre, The Cochrane Collaboration, 2011.

\section{Teitel 2004}

Teitel JM, Barnard D, Israels SJ, Lillicrap D, Poon MC, Sek J. Home care management of haemophilia. Haemophilia 2004;10(2):118-33. [MEDLINE: 14962201]

\section{van den Berg 2002}

van den Berg HM, Fischer K, van der Born JG, Roosendaal G, Mauser-Bunschoten EP. Effects of prophylactic treatment regimens in children with severe haemophilia: a comparison of different strategies. Haemophilia 2002;8(S2):43.

* Indicates the major publication for the study 


\section{CHARACTERISTICS OF STUDIES}

\section{Characteristics of included studies [ordered by study ID]}

\section{Aronstam 1976}

\begin{tabular}{ll}
\hline Methods & $\begin{array}{l}\text { Cross-over study. } \\
\text { Time unit: school term. } \\
\text { Randomised clinical trial. }\end{array}$ \\
\hline Participants & $\begin{array}{l}\text { Country: England. } \\
\text { Participants: males with hemophilia A. } \\
\text { (factor VIII }<1 \%) . \\
\text { Age Range: } 13-17 \text { years. } \\
\text { Number enrolled: } 9 .\end{array}$ \\
\hline Interventions & $\begin{array}{l}\text { Factor VIII concentrate. } \\
\text { (Blood Products Laboratory - UK). } \\
\text { Arm A: } 0.25 \text { U/kg once weekly. } \\
\text { Arm B: } 0.01 \text { U/kg once weekly. }\end{array}$ \\
\hline Outcomes & Bleeding events or frequency. \\
\hline Notes & \\
\hline
\end{tabular}

Notes

Risk of bias

\begin{tabular}{|c|c|c|}
\hline Bias & Authors' judgement & Support for judgement \\
\hline $\begin{array}{l}\text { Random sequence generation (selection } \\
\text { bias) }\end{array}$ & Unclear risk & $\begin{array}{l}\text { The authors did not specify sequence gen- } \\
\text { eration methods but specified that it was } \\
\text { generated by the Wessex Medical Informa- } \\
\text { tion Unit }\end{array}$ \\
\hline Allocation concealment (selection bias) & Low risk & $\begin{array}{l}\text { Quote: “...the random allocation of trial } \\
\text { subjects to the different regimens at the be- } \\
\text { ginning of each trial term was made by the } \\
\text { Wessex Medical Information Unit" }\end{array}$ \\
\hline $\begin{array}{l}\text { Blinding (performance bias and detection } \\
\text { bias) } \\
\text { All outcomes }\end{array}$ & Low risk & $\begin{array}{l}\text { Patients were blinded to the assignment } \\
\text { treatment; clinicians and assessors were un- } \\
\text { blinded }\end{array}$ \\
\hline $\begin{array}{l}\text { Incomplete outcome data (attrition bias) } \\
\text { All outcomes }\end{array}$ & Low risk & No missing outcome data. \\
\hline Selective reporting (reporting bias) & Low risk & $\begin{array}{l}\text { The study protocol is not available but the } \\
\text { published reports include all expected out- } \\
\text { comes }\end{array}$ \\
\hline
\end{tabular}


Aronstam 1976 (Continued)

\begin{tabular}{|c|c|c|}
\hline Other bias & Unclear risk & Cross-over study without washout period \\
\hline
\end{tabular}

\begin{tabular}{ll}
\hline Aronstam $\mathbf{1 9 7 7}$ & \\
\hline Methods & $\begin{array}{l}\text { Cross-over study. } \\
\text { Time unit: school term. } \\
\text { Randomized clinical trial. }\end{array}$ \\
\hline Participants & $\begin{array}{l}\text { Country: England. } \\
\text { Participants: males with hemophilia A (factor VIII < 1\%). } \\
\text { Age Range: } 13-17 \text { years. } \\
\text { Number enrolled: } 4 . \\
\text { All patients completed the study. }\end{array}$ \\
\hline Interventions & $\begin{array}{l}\text { Cryoprecipitate (prepared by Wessex Regional Transfusion Centre) or Kryobulin (pre- } \\
\text { pared by Serological Products, UK). } \\
\text { Arm A: raise factor VIII to } 15 \% \text { twice weekly. } \\
\text { Arm B: raise factor VIII to 30\% twice weekly. }\end{array}$ \\
\hline Outcomes & Bleeding events or frequency. \\
\hline Notes & \begin{tabular}{l}
\hline \\
\hline
\end{tabular}
\end{tabular}

\section{Risk of bias}

Bias

Random sequence generation (selection Unclear risk bias)

\section{Authors' judgement}

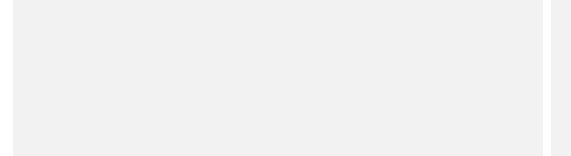

Allocation concealment (selection bias) Unclear risk

Blinding (performance bias and detection Low risk bias)

All outcomes

\begin{tabular}{l|l|l}
\hline $\begin{array}{l}\text { Incomplete outcome data (attrition bias) } \\
\text { All outcomes }\end{array}$ & Low risk & No missing outcome data. \\
\hline Selective reporting (reporting bias) & Low risk & $\begin{array}{l}\text { The study protocol is not available but the } \\
\text { published reports include all expected out- } \\
\text { comes }\end{array}$
\end{tabular}

\section{Support for judgement}

The authors reported they used a random sequence generation but did not give details about methods of sequence generation: Quote:" The boys were allocated to different treatment schedules at random at the start of the trial....."

The authors did not specify methods of concealment.

Patients and clinicians were blinded to the assignment treatment

comes 
Aronstam 1977 (Continued)

\begin{tabular}{|c|}
\hline Other bias \\
\hline
\end{tabular}

Carlsson 1997

\begin{tabular}{|c|c|c|}
\hline Methods & \multicolumn{2}{|c|}{$\begin{array}{l}\text { Cross-over study. } \\
\text { 1-year duration. } \\
\text { Time unit: } 6 \text { months. } \\
\text { Randomized clinical trial. }\end{array}$} \\
\hline Participants & \multicolumn{2}{|c|}{$\begin{array}{l}\text { Country: Sweden. } \\
\text { Participants: samples with clinically severe hemophilia A (factor VIII < 2\%). } \\
\text { Age range: } 8-42 \text { years. } \\
\text { Number enrolled: } 21 . \\
\text { Number completed: } 14 .\end{array}$} \\
\hline Interventions & \multicolumn{2}{|c|}{$\begin{array}{l}\text { Factor VIII concentrate (monoclonal antibody plasma derived, high-purity plasma-de- } \\
\text { rived, or recombinant) }\end{array}$} \\
\hline Outcomes & \multicolumn{2}{|c|}{ Bleeding events or frequency. } \\
\hline \multicolumn{3}{|l|}{ Notes } \\
\hline \multicolumn{3}{|l|}{ Risk of bias } \\
\hline Bias & Authors' judgement & Support for judgement \\
\hline $\begin{array}{l}\text { Random sequence generation (selection } \\
\text { bias) }\end{array}$ & Unclear risk & $\begin{array}{l}\text { Published report specifies that is a random } \\
\text { sequence generation but not defines meth- } \\
\text { ods of sequence generation }\end{array}$ \\
\hline Allocation concealment (selection bias) & Unclear risk & $\begin{array}{l}\text { The authors did not specify methods of } \\
\text { concealment. }\end{array}$ \\
\hline $\begin{array}{l}\text { Blinding (performance bias and detection } \\
\text { bias) } \\
\text { All outcomes }\end{array}$ & High risk & No blinding. \\
\hline $\begin{array}{l}\text { Incomplete outcome data (attrition bias) } \\
\text { All outcomes }\end{array}$ & Low risk & Reason of withdrawal were provided. \\
\hline Selective reporting (reporting bias) & Low risk & $\begin{array}{l}\text { The study protocol is not available but the } \\
\text { published reports include all expected out- } \\
\text { comes }\end{array}$ \\
\hline Other bias & Unclear risk & Cross-over study without washout period. \\
\hline
\end{tabular}

Clotting factor concentrates given to prevent bleeding and bleeding-related complications in people with hemophilia A or B (Review) 
Gringeri 2011

\begin{tabular}{l|l}
\hline Methods & $\begin{array}{l}10 \text { years duration. } \\
\text { Randomised clinical trial. }\end{array}$ \\
\hline Participants & $\begin{array}{l}\text { Country: Italy. } \\
\text { Participants: male with severe hemophilia A (factor VIII level }<1 \%) \\
\text { Median age: } 4 \text { years (age less than 7 years). } \\
\text { Number enrolled: } 40 .\end{array}$ \\
\hline Interventions & $\begin{array}{l}\text { Recombinant factor VIII concentrate (Recombinate). } \\
\text { Arm A:25 IU per kilogram of body weight } 3 \text { times a week. } \\
\text { Arm B: } 25 \text { IU per kilogram of body weight until complete healing }\end{array}$ \\
\hline Outcomes & Joint deterioration, bleed frequency. \\
\hline Notes & \\
\hline
\end{tabular}

Risk of bias

\begin{tabular}{l|ll}
\hline Bias & Authors' judgement & Support for judgement \\
\hline $\begin{array}{l}\text { Random sequence generation (selection } \\
\text { bias) }\end{array}$ & Low risk & $\begin{array}{l}\text { Quote: “ centralized allocation system } \\
\text { based on a computer generated randomiza- } \\
\text { tion list....” }\end{array}$ \\
\hline Allocation concealment (selection bias) & Low risk & $\begin{array}{l}\text { Quote: “ patients were centrally ran- } \\
\text { domised to be treated on prophylaxis with. } \\
\text {...” }\end{array}$ \\
\hline
\end{tabular}

Blinding (performance bias and detection Low risk bias)

All outcomes

Patients were unblinded, but the outcome assessors (for musculoskeletal and radiologic evaluation) were blinded

Incomplete outcome data (attrition bias) Low risk All outcomes

Missing data have been in managed intention-to-treat analysis by last observation carried forward technique. List of cause for withdrawal: 9 patients refused randomization; 3 patients suffered for more than 2 bleeding episodes in the same joints; 3 patients had not bled in the previous 6 months, 1 child had radiologic signs of arthropathy, 1 child belonged to an unreliable (dysfunctional) family

Selective reporting (reporting bias) Low risk

The study protocol is not available but the published reports include all expected outcomes

Other bias

High risk

Significant degree of cross-over between treatment arms.

Clotting factor concentrates given to prevent bleeding and bleeding-related complications in people with hemophilia A or B (Review) 
Manco-Johnson 2007

\begin{tabular}{|c|c|c|}
\hline Methods & \multicolumn{2}{|c|}{$\begin{array}{l}9 \text { years duration. } \\
\text { Time unit: mean } 49 \text { month ( } 48-58 \text { month). } \\
\text { Multicentre, open-label trial randomised clinical trial. }\end{array}$} \\
\hline Participants & \multicolumn{2}{|c|}{$\begin{array}{l}\text { Country: USA. } \\
\text { Participants: male with severe and moderate-severe hemophilia A (factor VIII level <2\%) } \\
\text { Age: mean } 1.6 \text { years (age less than } 30 \text { month in all participants) } \\
\text { Number enrolled: } 65 \text {. }\end{array}$} \\
\hline Interventions & \multicolumn{2}{|c|}{$\begin{array}{l}\text { Recombinant factor VIII concentrate (Kogenate or Kogenate Bayer) } \\
\text { Arm A: } 25 \mathrm{IU} \text { of factor VIII per kilogram of body weight every other day to prevent } \\
\text { bleeding. When hemarthroses occurred during prophylaxis, patients were treated with } \\
40 \mathrm{IU} \text { per kg at the time of joint haemorrhage } \\
\text { Arm B: } 40 \mathrm{IU} \text { per kg of body weight at the time of joint haemorrhage and } 20 \mathrm{IU} \text { at } 24 \\
\text { hours and } 72 \text { hours after the first dose }\end{array}$} \\
\hline Outcomes & \multicolumn{2}{|c|}{$\begin{array}{l}\text { Primary outcome: preservation of index-joint structure. } \\
\text { Secondary outcomes: number of bleeding events, number of infusion, total of factor } \\
\text { VIII units administrated }\end{array}$} \\
\hline \multicolumn{3}{|l|}{ Notes } \\
\hline \multicolumn{3}{|l|}{ Risk of bias } \\
\hline Bias & Authors' judgement & Support for judgement \\
\hline $\begin{array}{l}\text { Random sequence generation (selection } \\
\text { bias) }\end{array}$ & Unclear risk & No information provided. \\
\hline Allocation concealment (selection bias) & Low risk & $\begin{array}{l}\text { Quote: "randomisation was performed } \\
\text { centrally and stratified by site in permuted } \\
\text { blocks of } 2,4 \text { or } 6 . "\end{array}$ \\
\hline $\begin{array}{l}\text { Blinding (performance bias and detection } \\
\text { bias) } \\
\text { All outcomes }\end{array}$ & Low risk & $\begin{array}{l}\text { Quote: "The radiologists who reviewed } \\
\text { joint images, the physiotherapists who per- } \\
\text { formed assays were unaware of the patients' } \\
\text { treatment assignments and status with re- } \\
\text { spect to a history of bleeding" }\end{array}$ \\
\hline $\begin{array}{l}\text { Incomplete outcome data (attrition bias) } \\
\text { All outcomes }\end{array}$ & Low risk & $\begin{array}{l}\text { Missing data have been managed in in- } \\
\text { tention-to-treat analysis by last observa- } \\
\text { tion carried forward technique. Patients re- } \\
\text { moved in by protocol analysis: } 5 / 32 \text { (list } \\
\text { of causes for withdrawal: } 2 \text { patients devel- } \\
\text { oped high titre inhibitors; } 1 \text { patient had } \\
\text { joint damage; } 2 \text { patients dropped out) in } \\
\text { the prophylaxis group and } 11 / 33 \text { (list of } \\
\text { causes for withdrawal: } 3 \text { for life threatening } \\
\text { haemorrhage; } 6 \text { patients had joint damage; }\end{array}$ \\
\hline
\end{tabular}

Clotting factor concentrates given to prevent bleeding and bleeding-related complications in people with hemophilia A or B (Review) 
Manco-Johnson 2007 (Continued)

1 patient dropped out; 1 was lost to follow up) in the on-demand group

\begin{tabular}{|c|c|c|}
\hline Selective reporting (reporting bias) & Low risk & $\begin{array}{l}\text { The study protocol is published at the end } \\
\text { of enrolment but the published reports in- } \\
\text { clude all expected outcomes and analysed } \\
\text { data following protocol publication }\end{array}$ \\
\hline Other bias & Low risk & No risk of bias. \\
\hline
\end{tabular}

Morfini 1976

\begin{tabular}{ll}
\hline Methods & $\begin{array}{l}\text { Cross-over study. } \\
1 \text { year duration. } \\
\text { Time unit: } 3 \text {-month cycles (A-B-A-B versus B-A-B-A). } \\
\text { Randomized clinical trial. }\end{array}$ \\
\hline Participants & $\begin{array}{l}\text { Country: Italy. } \\
\text { Participants: males with hemophilia B (factor IX }<1 \%) . \\
\text { Age range: } 5 \text { - } 45 \text { years. } \\
\text { Number enrolled: } 10 .\end{array}$ \\
\hline Interventions & $\begin{array}{l}\text { Factor IX concentrate (Bebulin). } \\
\text { Arm A: } 7.5 \text { U/kg twice weekly. } \\
\text { Arm B: } 15 \text { U/kg weekly. }\end{array}$ \\
\hline Outcomes & Bleeding events or frequency, joint deterioration. \\
\hline Notes & \\
\hline
\end{tabular}

Risk of bias

\begin{tabular}{l|ll}
\hline Bias & Authors' judgement & Support for judgement \\
\hline $\begin{array}{l}\text { Random sequence generation (selection } \\
\text { bias) }\end{array}$ & Unclear risk & No information provided. \\
\hline $\begin{array}{l}\text { Allocation concealment (selection bias) } \\
\text { Llinding (performance bias and detection }\end{array}$ & High risk & $\begin{array}{l}\text { Quote: “ allocation to treatment protocols } \\
\text { was made on the basis of random envelopes. } \\
\text { All outcomes }\end{array}$ \\
\hline
\end{tabular}

Incomplete outcome data (attrition bias) Unclear risk

No missing data.

All outcomes

Clotting factor concentrates given to prevent bleeding and bleeding-related complications in people with hemophilia A or B (Review) 
Morfini 1976 (Continued)

\begin{tabular}{|c|c|c|}
\hline Selective reporting (reporting bias) & Low risk & $\begin{array}{l}\text { The study protocol is not available but the } \\
\text { published reports include all expected out- } \\
\text { comes }\end{array}$ \\
\hline Other bias & Unclear risk & Cross-over study without washout period. \\
\hline
\end{tabular}

IU: international units

Characteristics of excluded studies [ordered by study ID]

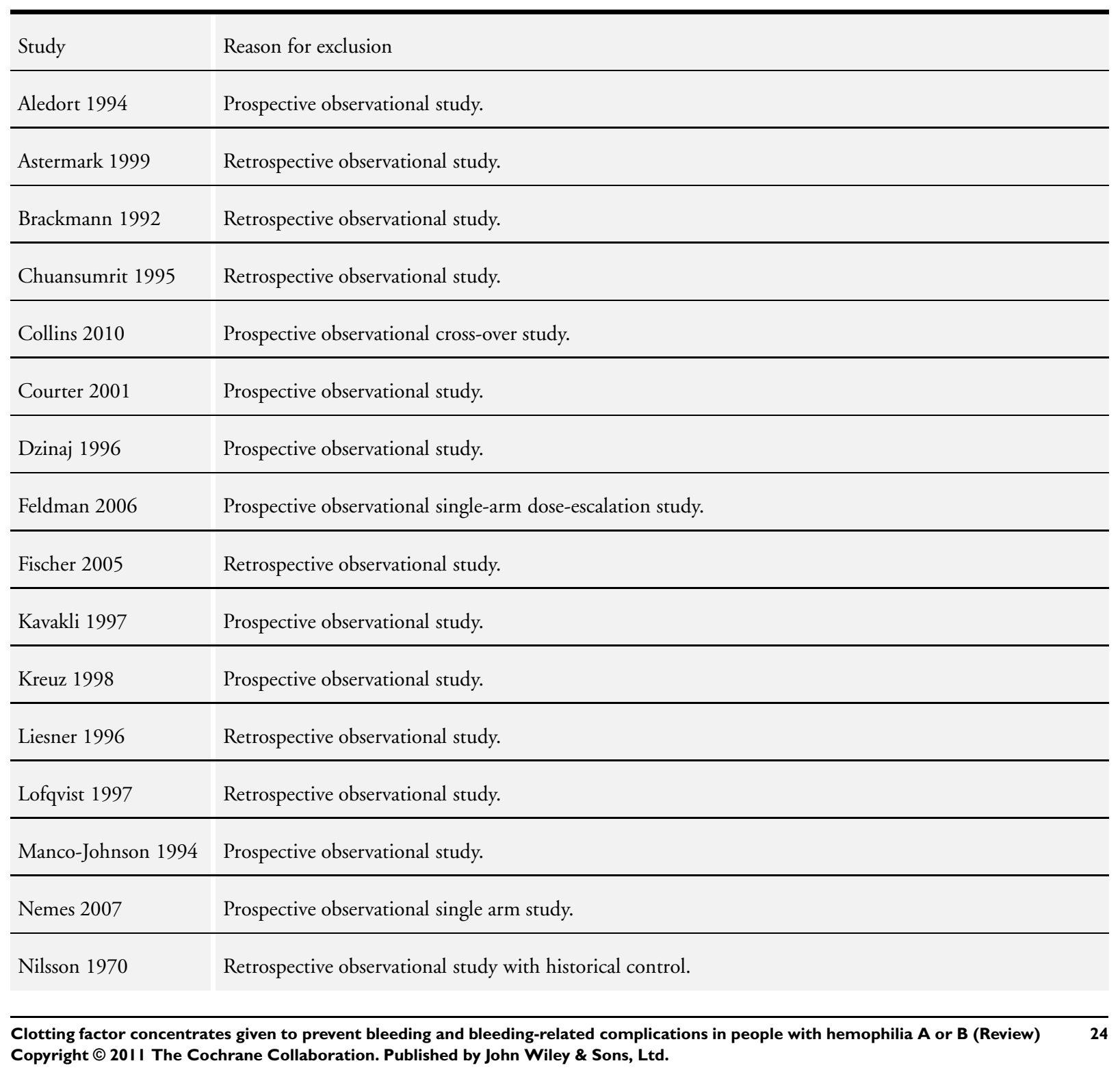


(Continued)

\begin{tabular}{|c|c|}
\hline Nilsson 1976 & Prospective observational study with historical control. \\
\hline Nilsson 1992 & Retrospective observational study. \\
\hline Petrini 1991 & Retrospective observational study. \\
\hline Petrini 2001 & Retrospective observational study. \\
\hline Pettersson 1981 & Retrospective observational study with historical control. \\
\hline Ramsay 1973 & Prospective observational study. \\
\hline Royal 2002 & Retrospective observational study with parallel groups. \\
\hline Schimpf 1977 & Prospective observational cross-over study. \\
\hline Schobess 2008 & Prospective observational study. \\
\hline Smith 1996 & Retrospective observational switch study. \\
\hline Szucs 1996 & Prospective observational study. \\
\hline Tagliaferri 2008 & Retrospective observational switch study. \\
\hline Tusell 2002 & Retrospective observational study. \\
\hline Van den Berg 2001 & Retrospective observational single-arm study. \\
\hline Wu 2011 & Prospective observation with historical control. \\
\hline
\end{tabular}


DATA ANDANALYSES

Comparison 1. Standard prophylaxis versus placebo (factor VIII concentrate (post-infusion level)

\begin{tabular}{|c|c|c|c|c|}
\hline Outcome or subgroup title & $\begin{array}{l}\text { No. of } \\
\text { studies }\end{array}$ & $\begin{array}{c}\text { No. of } \\
\text { participants }\end{array}$ & Statistical method & Effect size \\
\hline 1 Bleed frequency & 1 & & Rate difference (Fixed, 95\% CI) & Totals not selected \\
\hline 2 Morbidity (length of stay) & 1 & & Rate difference (Fixed, 95\% CI) & Totals not selected \\
\hline
\end{tabular}

Comparison 2. Standard prophylaxis versus on-demand treatment (factor VIII concentrate)

\begin{tabular}{|c|c|c|c|c|}
\hline Outcome or subgroup title & $\begin{array}{l}\text { No. of } \\
\text { studies }\end{array}$ & $\begin{array}{c}\text { No. of } \\
\text { participants }\end{array}$ & Statistical method & Effect size \\
\hline 1 Bleed frequency & 2 & & Rate Ratio (Random, 95\% CI) & $0.30[0.12,0.76]$ \\
\hline 2 Joint bleeding & 2 & & Rate Ratio (Random, 95\% CI) & $0.22[0.08,0.63]$ \\
\hline 3 Joint function protection & 2 & & Risk Difference (M-H, Fixed, 95\% CI) & Totals not selected \\
\hline 3.1 Primary prophylaxis & 2 & & Risk Difference (M-H, Fixed, 95\% CI) & $0.0[0.0,0.0]$ \\
\hline 3.2 Secondary prophylaxis & 1 & & Risk Difference (M-H, Fixed, 95\% CI) & $0.0[0.0,0.0]$ \\
\hline 4 Quality of Life & 1 & & Mean Difference (IV, Fixed, 95\% CI) & Totals not selected \\
\hline $\begin{array}{l}5 \text { Factor concentrate usage }[\mathrm{x} 1000 \\
\mathrm{IU}]\end{array}$ & 2 & 105 & Mean Difference (IV, Fixed, 95\% CI) & $5.27[4.23,6.32]$ \\
\hline 6 Adverse events & 2 & & Risk Difference (M-H, Random, 95\% CI) & Subtotals only \\
\hline 6.1 Infections (All patients) & 2 & 105 & Risk Difference (M-H, Random, 95\% CI) & $0.14[-0.14,0.42]$ \\
\hline 6.2 Inhibitors (All patients) & 2 & 105 & Risk Difference (M-H, Random, 95\% CI) & $0.06[-0.03,0.15]$ \\
\hline $\begin{array}{l}\text { 6.3 Infections (Patients with } \\
\text { CVC) }\end{array}$ & 1 & 54 & Risk Difference (M-H, Random, 95\% CI) & $-0.03[-0.26,0.19]$ \\
\hline $\begin{array}{l}6.4 \text { Inhibitors (Patients with } \\
\text { CVC) }\end{array}$ & 1 & 54 & Risk Difference (M-H, Random, 95\% CI) & $-0.01[-0.11,0.10]$ \\
\hline
\end{tabular}

Comparison 3. Standard prophylaxis versus alternative prophylaxis (factor VIII concentrate (post-infusion level)

\begin{tabular}{lcccc} 
Outcome or subgroup title & $\begin{array}{c}\text { No. of } \\
\text { studies }\end{array}$ & $\begin{array}{c}\text { No. of } \\
\text { participants }\end{array}$ & Statistical method & Effect size \\
\hline 1 Bleed frequency & 1 & Rate difference (Fixed, 95\% CI) & Totals not selected \\
\hline
\end{tabular}

Clotting factor concentrates given to prevent bleeding and bleeding-related complications in people with hemophilia A or B (Review) 


\begin{tabular}{|c|c|c|c|c|}
\hline Outcome or subgroup title & $\begin{array}{l}\text { No. of } \\
\text { studies }\end{array}$ & $\begin{array}{c}\text { No. of } \\
\text { participants }\end{array}$ & Statistical method & Effect size \\
\hline 1 Bleed frequency & 1 & & Rate difference (Fixed, 95\% CI) & Totals not selected \\
\hline $\begin{array}{l}2 \text { Clotting factor concentrate } \\
\text { usage }[\mathrm{x} 1000]\end{array}$ & 1 & & Mean Difference (IV, Fixed, 95\% CI) & Subtotals only \\
\hline
\end{tabular}

Comparison 5. Standard prophylaxis versus alternative prophylaxis (factor IX concentrate)

\begin{tabular}{lcccc} 
Outcome or subgroup title & $\begin{array}{c}\text { No. of } \\
\text { studies }\end{array}$ & $\begin{array}{c}\text { No. of } \\
\text { participants }\end{array}$ & Statistical method & Effect size \\
\hline 1 Bleed frequency & 1 & Rate difference (Fixed, 95\% CI) & Totals not selected \\
\hline
\end{tabular}

Analysis I.I. Comparison I Standard prophylaxis versus placebo (factor VIII concentrate (post-infusion level), Outcome I Bleed frequency.

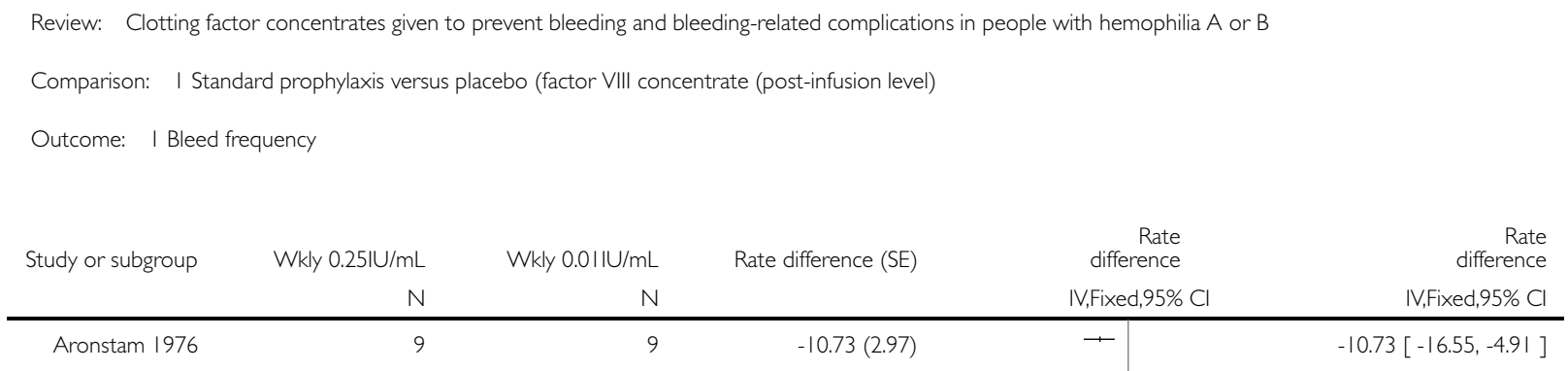




\section{Analysis I.2. Comparison I Standard prophylaxis versus placebo (factor VIII concentrate (post-infusion} level), Outcome 2 Morbidity (length of stay).

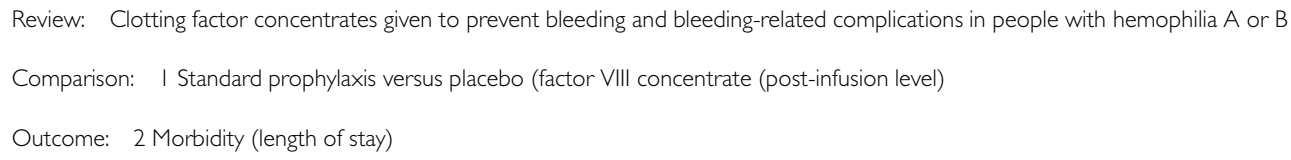

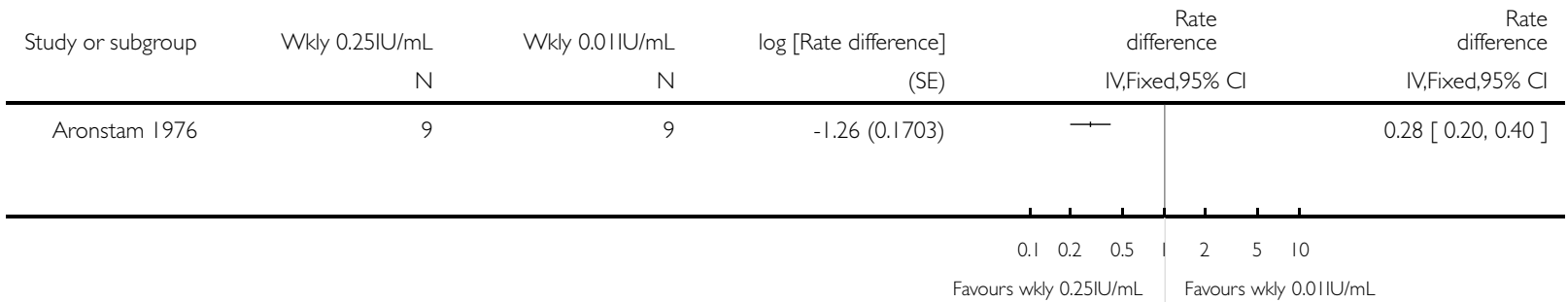

Analysis 2.I. Comparison 2 Standard prophylaxis versus on-demand treatment (factor VIII concentrate), Outcome I Bleed frequency.

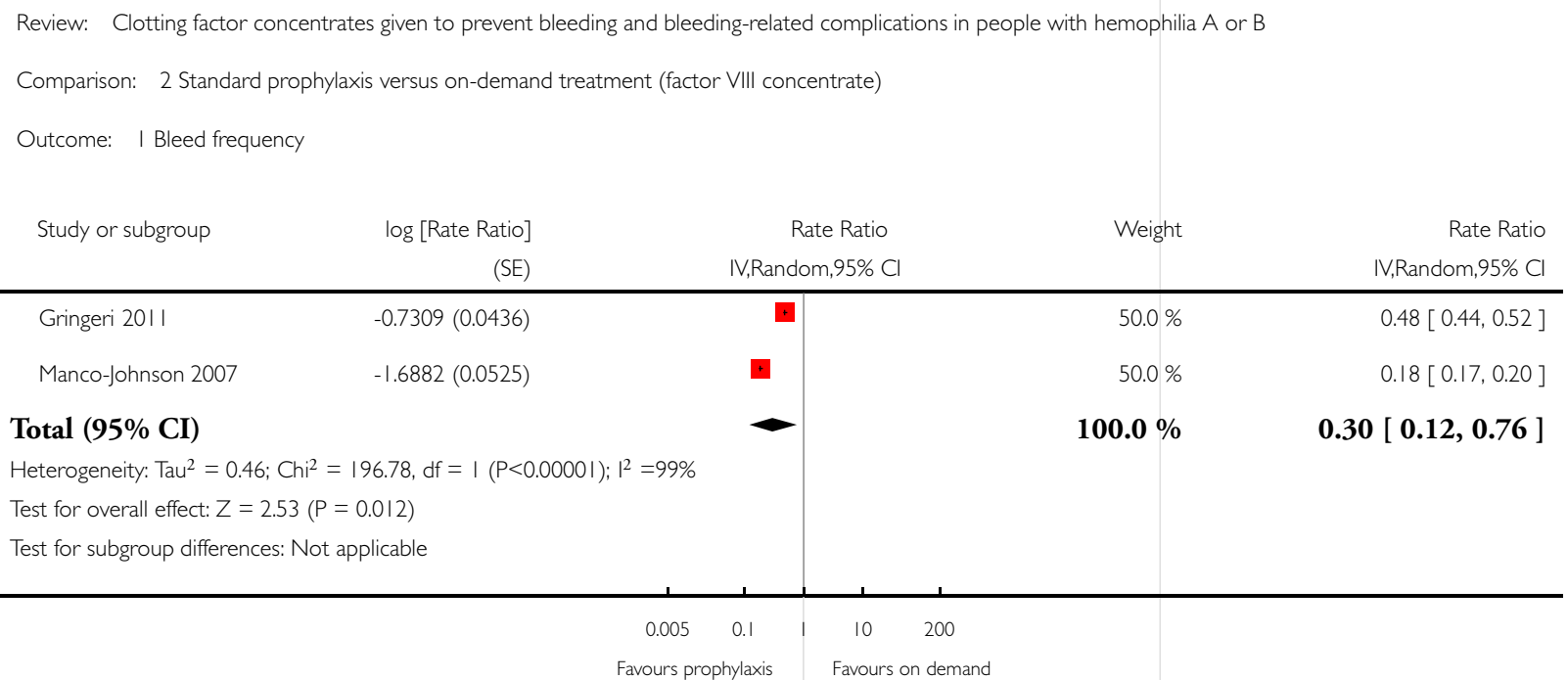


Analysis 2.2. Comparison 2 Standard prophylaxis versus on-demand treatment (factor VIII concentrate), Outcome 2 Joint bleeding.

Review: Clotting factor concentrates given to prevent bleeding and bleeding-related complications in people with hemophilia A or B

Comparison: 2 Standard prophylaxis versus on-demand treatment (factor VIII concentrate)

Outcome: 2 Joint bleeding

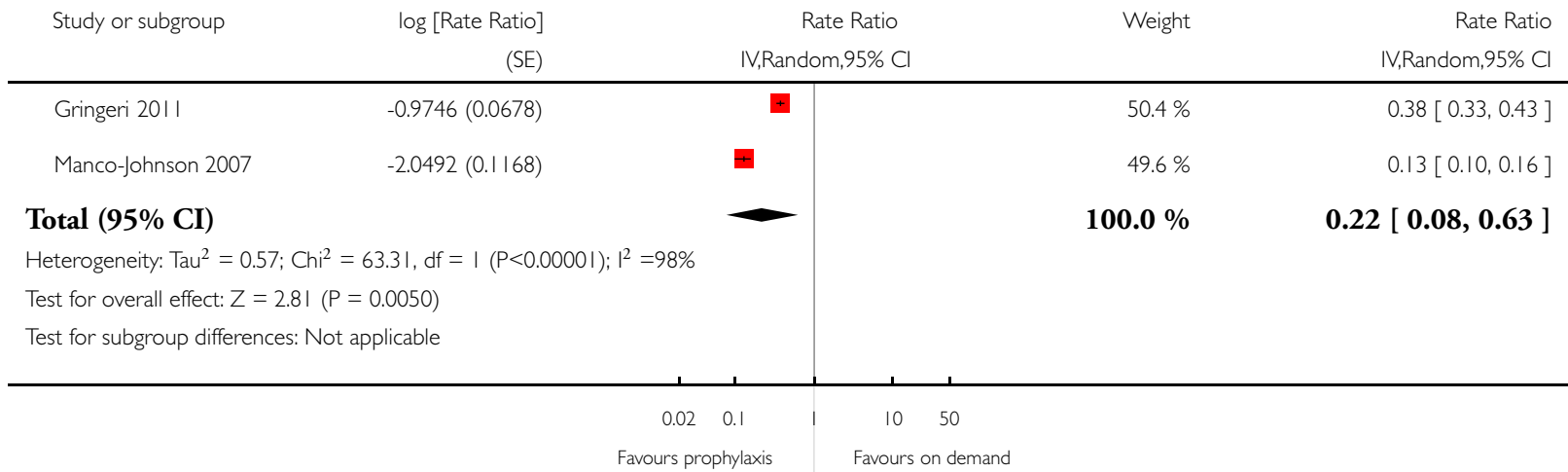

Analysis 2.3. Comparison 2 Standard prophylaxis versus on-demand treatment (factor VIII concentrate), Outcome 3 Joint function protection.

Review: Clotting factor concentrates given to prevent bleeding and bleeding-related complications in people with hemophilia A or B

Comparison: 2 Standard prophylaxis versus on-demand treatment (factor VIII concentrate)

Outcome: 3 Joint function protection

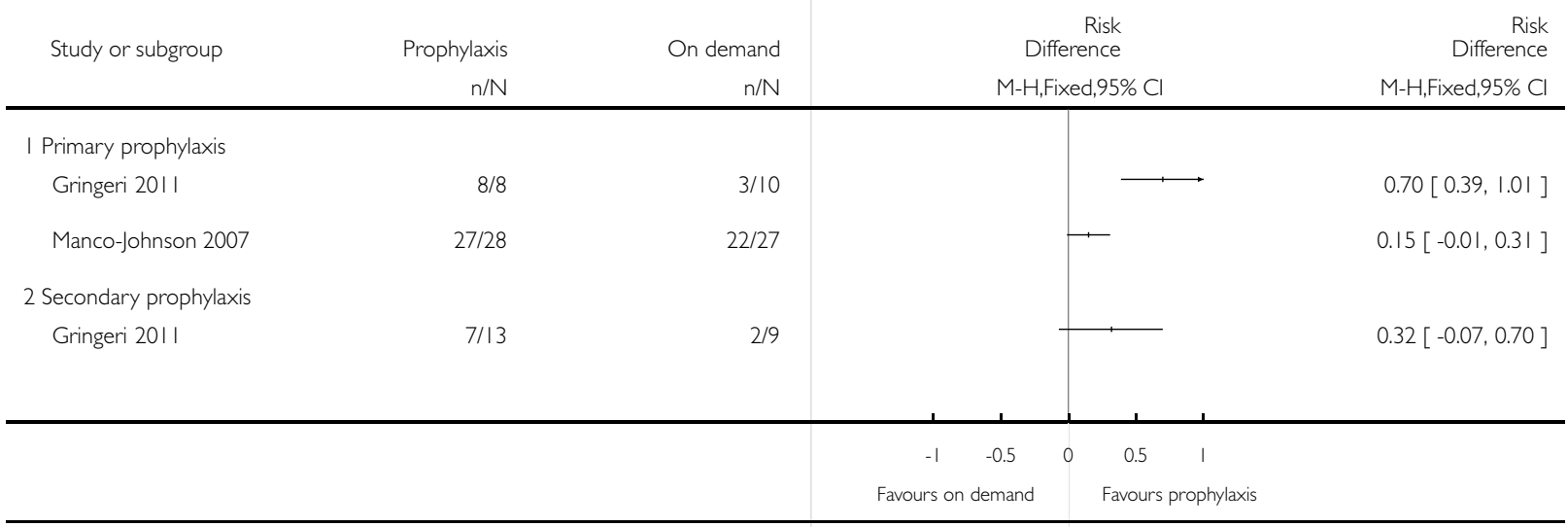

Clotting factor concentrates given to prevent bleeding and bleeding-related complications in people with hemophilia A or B (Review) 
Analysis 2.4. Comparison 2 Standard prophylaxis versus on-demand treatment (factor VIII concentrate), Outcome 4 Quality of Life.

Review: Clotting factor concentrates given to prevent bleeding and bleeding-related complications in people with hemophilia A or B

Comparison: 2 Standard prophylaxis versus on-demand treatment (factor VIII concentrate)

Outcome: 4 Quality of Life

\begin{tabular}{|c|c|c|c|c|c|c|c|c|c|c|}
\hline \multirow[t]{2}{*}{ Study or subgroup } & \multirow{2}{*}{$\begin{array}{r}\text { On demand } \\
\mathrm{N}\end{array}$} & \multicolumn{3}{|c|}{ Prophylaxis } & \multicolumn{5}{|c|}{$\begin{array}{r}\text { Mean } \\
\text { Difference }\end{array}$} & \multirow{2}{*}{$\begin{array}{r}\text { Mear } \\
\text { Difference } \\
\text { IV,Fixed,95\% C }\end{array}$} \\
\hline & & Mean(SD) & N & Mean(SD) & & & xed, & $\% \mathrm{Cl}$ & & \\
\hline Gringeri 201I & 21 & $44(22.6)$ & 19 & I 1.27 (8.7) & & & & & • & $32.73[22.30,43.16]$ \\
\hline & & & & & -20 & -10 & 0 & 10 & 20 & \\
\hline
\end{tabular}


Analysis 2.5. Comparison 2 Standard prophylaxis versus on-demand treatment (factor VIII concentrate), Outcome 5 Factor concentrate usage [xI000 IU].

Review: Clotting factor concentrates given to prevent bleeding and bleeding-related complications in people with hemophilia A or B

Comparison: 2 Standard prophylaxis versus on-demand treatment (factor VIII concentrate)

Outcome: 5 Factor concentrate usage $[\times 1000 \mathrm{IU}]$

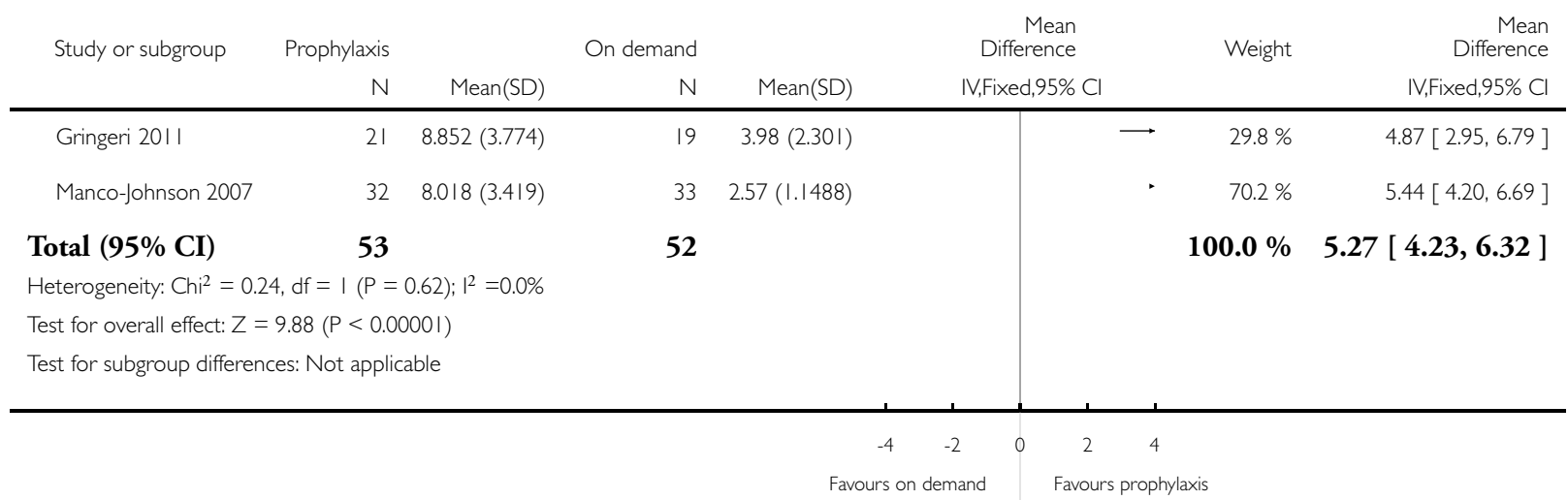


Analysis 2.6. Comparison 2 Standard prophylaxis versus on-demand treatment (factor VIII concentrate), Outcome 6 Adverse events.

Review: Clotting factor concentrates given to prevent bleeding and bleeding-related complications in people with hemophilia A or B

Comparison: 2 Standard prophylaxis versus on-demand treatment (factor VIII concentrate)

Outcome: 6 Adverse events

Study or subgroup

Prophylaxis On demand

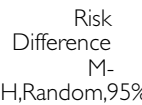

Weight

H,Random,95\%

Risk
Difference

H,Random, $95 \%$

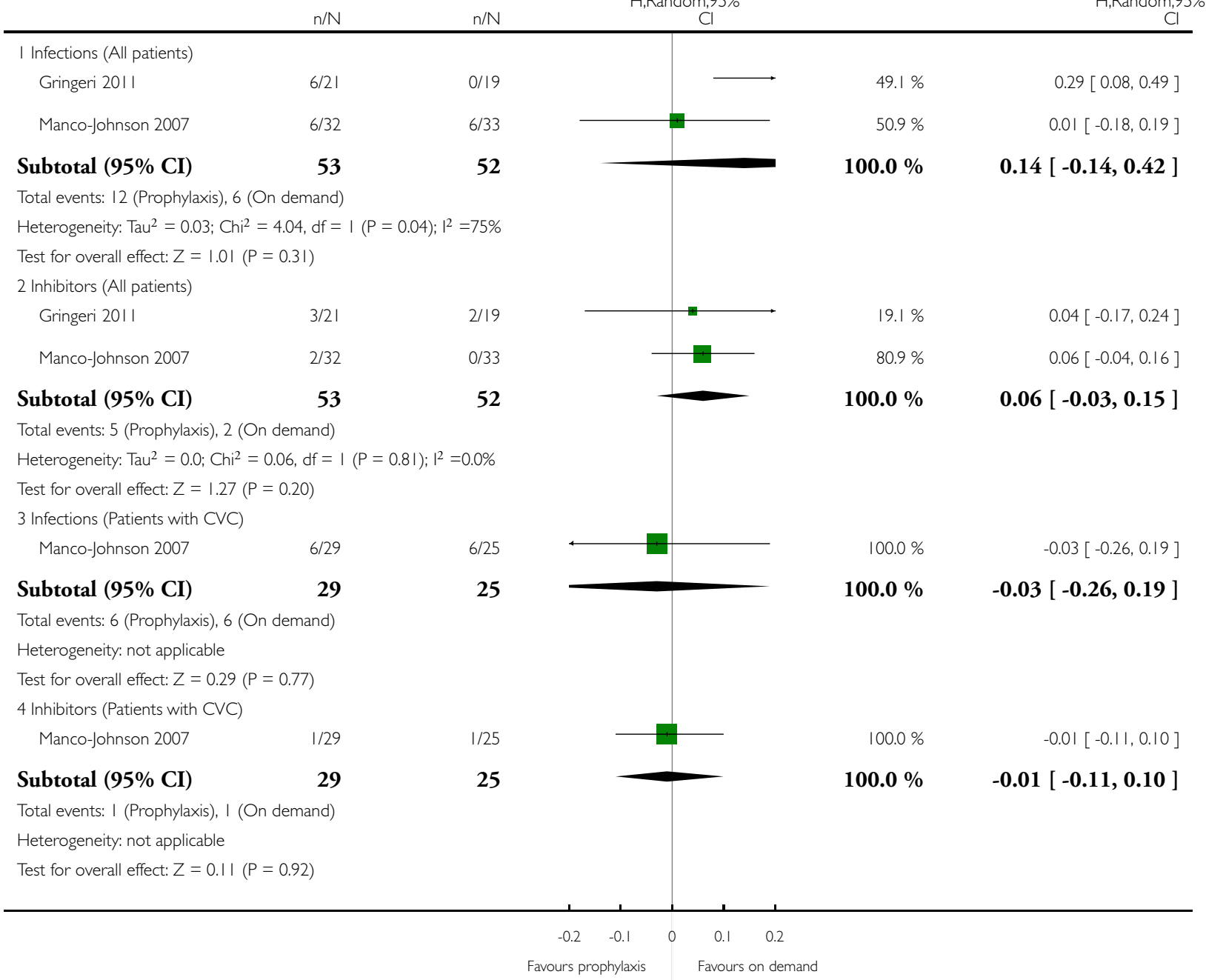

Clotting factor concentrates given to prevent bleeding and bleeding-related complications in people with hemophilia A or B (Review) 
Analysis 3.I. Comparison 3 Standard prophylaxis versus alternative prophylaxis (factor VIII concentrate (post-infusion level), Outcome I Bleed frequency.

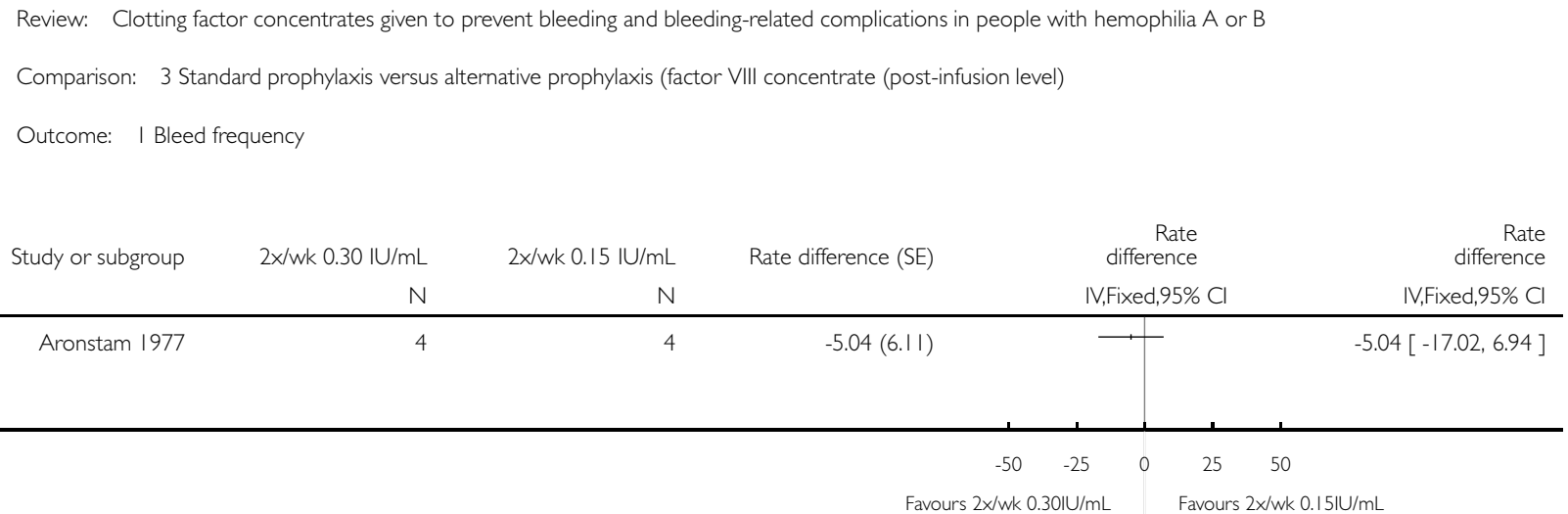

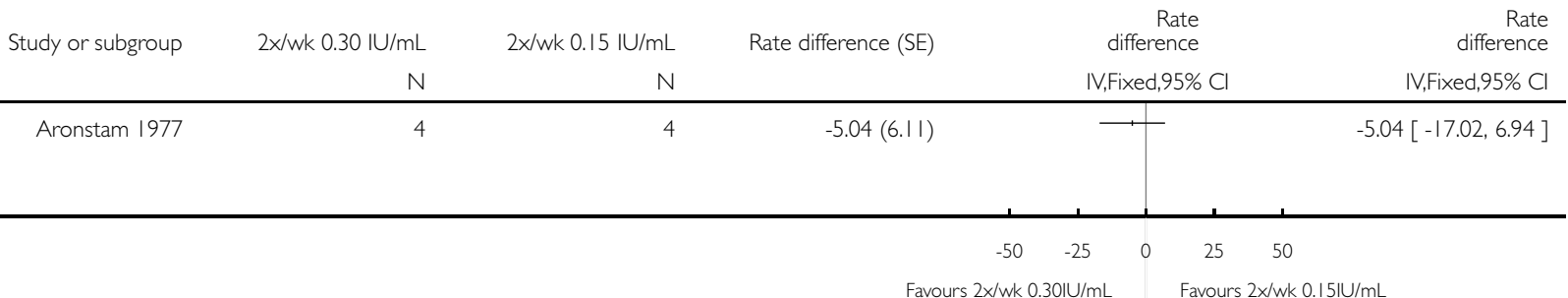

Analysis 4.I. Comparison 4 Standard prophylaxis versus alternative prophylaxis (factor VIII concentrate), Outcome I Bleed frequency.

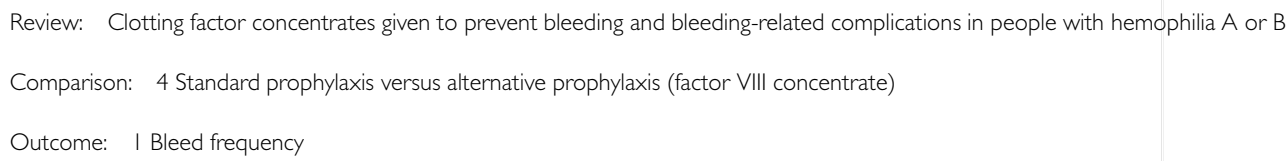

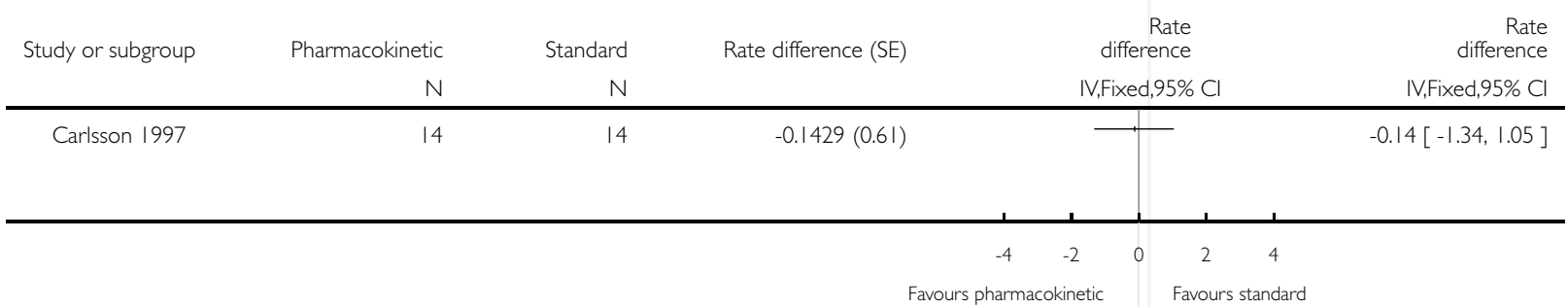


Analysis 4.2. Comparison 4 Standard prophylaxis versus alternative prophylaxis (factor VIII concentrate), Outcome 2 Clotting factor concentrate usage [x|000].

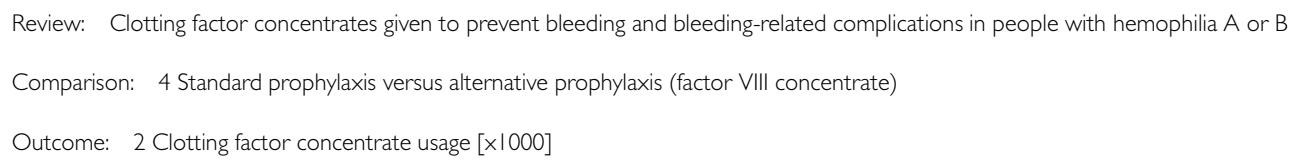

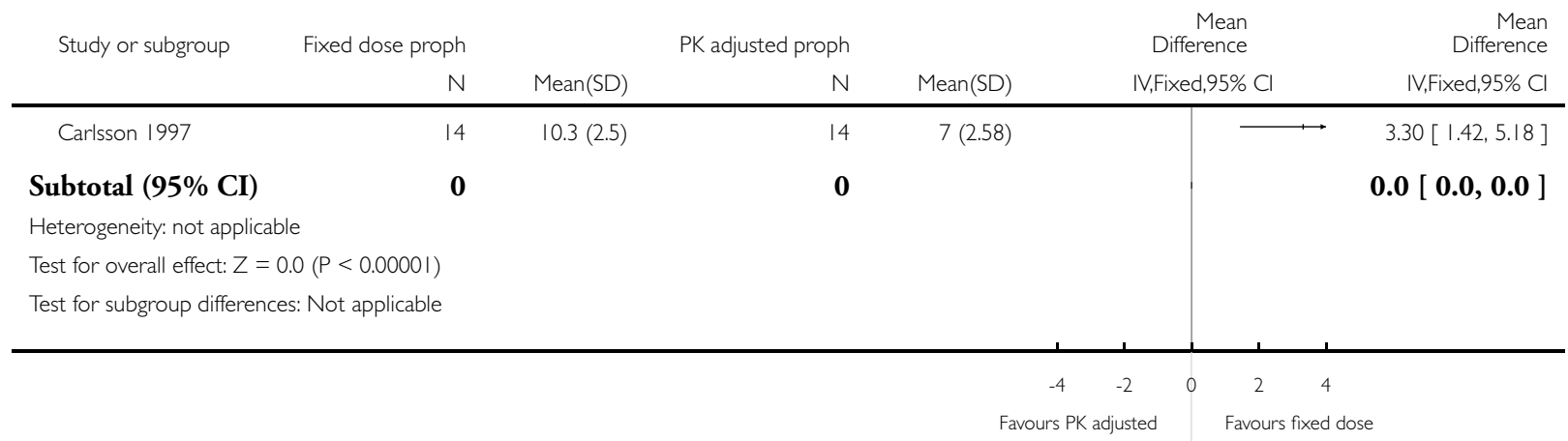

Analysis 5.I. Comparison 5 Standard prophylaxis versus alternative prophylaxis (factor IX concentrate), Outcome I Bleed frequency.

Review: Clotting factor concentrates given to prevent bleeding and bleeding-related complications in people with hemophilia A or B

Comparison: 5 Standard prophylaxis versus alternative prophylaxis (factor IX concentrate)

Outcome: I Bleed frequency

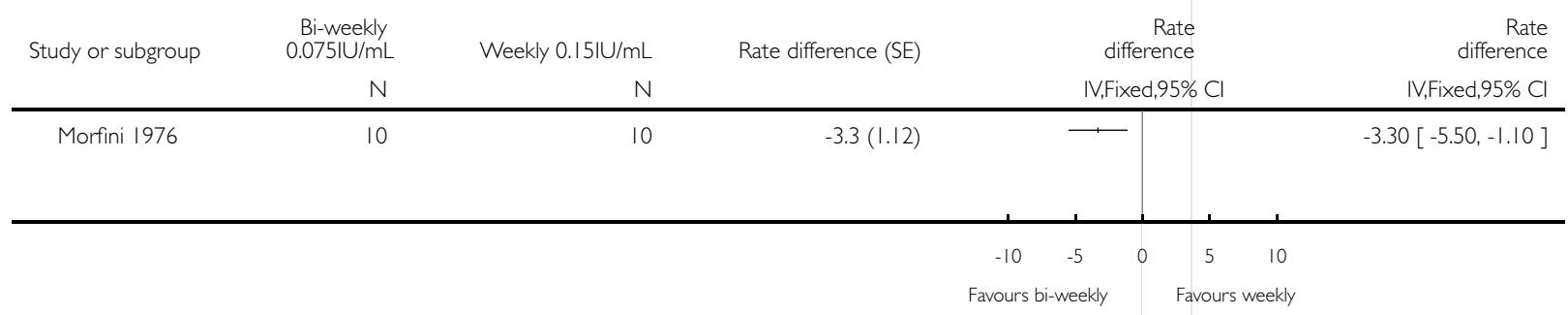


ADDITIONAL TABLES

Table 1. Additional non-randomised observational clinical studies

\begin{tabular}{|c|c|c|c|c|c|}
\hline Study ID & Methods & Participants & Interventions & Outcomes & Notes \\
\hline Aledort 1994 & $\begin{array}{l}\text { Prospective observa- } \\
\text { tional study. }\end{array}$ & $\begin{array}{l}\text { Coun- } \\
\text { try: Japan, USA, Eu- } \\
\text { rope. Cases: severe } \\
\text { hemophilia A, un- } \\
\text { der age } 25 \text { years. En- } \\
\text { rolled 66; controls } \\
411\end{array}$ & $\begin{array}{l}\text { Dose category in } \\
\mathrm{mcg} / \mathrm{kg} \text { body weight } \\
\text { per year. }\end{array}$ & $\begin{array}{l}\text { Orthopedic joint } \\
\text { score. }\end{array}$ & \\
\hline Astermark 1999 & $\begin{array}{l}\text { Retrospective obser- } \\
\text { vational study. }\end{array}$ & $\begin{array}{l}\text { Country: Swe- } \\
\text { den. Cases: severe } \\
\text { hemophilia A and } \\
\text { B. Hemophilia A = } \\
\text { 108; Hemophilia B } \\
=13\end{array}$ & $\begin{array}{l}\text { Clotting factor con- } \\
\text { centrates 25-40 IU/ } \\
\text { kg body } \\
\text { weight. Hemophilia } \\
\text { A: three times per } \\
\text { week. Hemophilia } \\
\text { B: } 2 \text { times per week }\end{array}$ & $\begin{array}{l}\text { Bleeding } \\
\text { episodes. Orthope- } \\
\text { dic joint score. }\end{array}$ & \\
\hline Brackmann 1992 & $\begin{array}{l}\text { Retrospective obser- } \\
\text { vational study. }\end{array}$ & $\begin{array}{l}\text { Country: } \\
\text { Germany. Cases: se- } \\
\text { vere hemophilia A, } \\
<16 \text { years of age in } \\
1978 \text {. Number en- } \\
\text { rolled: } 90\end{array}$ & $\begin{array}{l}\text { Clotting factor con- } \\
\text { centrate: no details } \\
\text { provided. }\end{array}$ & $\begin{array}{l}\text { Bleed- } \\
\text { ing episodes. Clini- } \\
\text { cal joint score. Radi- } \\
\text { ological joint score }\end{array}$ & \\
\hline Chuansumrit 1995 & $\begin{array}{l}\text { Prospective observa- } \\
\text { tional study. Single } \\
\text { arm. }\end{array}$ & $\begin{array}{l}\text { Country: Thailand. } \\
\text { Cases: } \\
\text { moderate and se- } \\
\text { vere hemophilia A. } \\
\text { Number enrolled: } 6\end{array}$ & $\begin{array}{l}\text { Clotting factor con- } \\
\text { centrate } 8-10 \mathrm{U} / \mathrm{kg} \\
\text { body weight twice } \\
\text { per week }\end{array}$ & $\begin{array}{l}\text { Bleeding episodes. } \\
\text { Days of hospitalisa- } \\
\text { tion. }\end{array}$ & \\
\hline Collins 2010 & $\begin{array}{l}\text { Prospective observa- } \\
\text { tional study. Cross- } \\
\text { over study }\end{array}$ & $\begin{array}{l}\text { Country: United } \\
\text { States, UK. Case: } \\
\text { severe hemophilia. } \\
\text { Enrolled: } 20\end{array}$ & rFVIII-FS & $\begin{array}{l}\text { Bleed- } \\
\text { ing episodes, joint } \\
\text { function, health re- } \\
\text { lated QoL, health } \\
\text { economics and sa- } \\
\text { fety }\end{array}$ & \\
\hline Courter 2001 & $\begin{array}{l}\text { Prospective observa- } \\
\text { tional label study. }\end{array}$ & $\begin{array}{l}\text { Country: Multina- } \\
\text { tional. Cases: severe } \\
\text { hemophilia A. Pre- } \\
\text { viously un- } \\
\text { treated patients. En- } \\
\text { rolled: } 27\end{array}$ & $\begin{array}{l}\text { Coagulation recom- } \\
\text { binant } \\
\text { factor BDDrFVIII. } \\
\text { Prophylaxis or on- } \\
\text { demand therapy }\end{array}$ & Bleeding episodes. & \\
\hline Dzinaj 1996 & $\begin{array}{l}\text { Prospective observa- } \\
\text { tional study. }\end{array}$ & $\begin{array}{l}\text { Country: Germany. } \\
\text { Cases: } \\
\text { early onset prophy- }\end{array}$ & $\begin{array}{l}\text { Clotting factor con- } \\
\text { centrate } \\
\text { (Humate P) } 30-40\end{array}$ & $\begin{array}{l}\text { Radiologic joint } \\
\text { score. }\end{array}$ & \\
\hline
\end{tabular}




\begin{tabular}{|c|c|c|c|c|c|}
\hline & & $\begin{array}{l}\text { laxis versus late on- } \\
\text { set of prophylaxis in } \\
\text { moderate or severe } \\
\text { hemophilia A). En- } \\
\text { rolled: Cases = } 10 \text {. } \\
\text { Controls = } 7\end{array}$ & $\begin{array}{l}\text { IU } / \mathrm{kg} \text { body weight } \\
\text { three times per week }\end{array}$ & & \\
\hline Feldman 2006 & $\begin{array}{l}\text { Prospective observa- } \\
\text { tional study. Single } \\
\text { arm dose escalation. }\end{array}$ & $\begin{array}{l}\text { Country: } \\
\text { Canada. Cases: se- } \\
\text { vere hemophilia A. } \\
\text { Enrolled: } 25\end{array}$ & $\begin{array}{l}\text { Clotting factor con- } \\
\text { centrate. } \\
\text { Step } 1 \\
\text { prophylaxis with } 50 \\
\text { IU } / \mathrm{kg} / \text { weekly } \\
\text { Step } 2 \text { prophylaxis } \\
\text { with } 30 \mathrm{IU} / \mathrm{kg} \text { twice } \\
\text { a week if patients } \\
\text { met excalation crite- } \\
\text { ria } \\
\text { Step } 325 \text { IU } / \mathrm{kg} \\
\text { on alternative days if } \\
\text { patients met excala- } \\
\text { tion criteria }\end{array}$ & Bleeding episodes. & $\begin{array}{l}\text { excalation criteria: } \\
\text { - target joint devel- } \\
\text { opment } \\
\text { - four or more bleed- } \\
\text { ing episodes } \\
\text { in a consecutive 3- } \\
\text { month period } \\
\text { - more than } 5 \text { joint } \\
\text { bleeding in any pe- } \\
\text { riod of time }\end{array}$ \\
\hline Fischer 2005 & $\begin{array}{l}\text { Retrospective obser- } \\
\text { vational study. }\end{array}$ & $\begin{array}{l}\text { Country: Nether- } \\
\text { lands. Cases: severe } \\
\text { hemophilia A. En- } \\
\text { rolled: } 61\end{array}$ & $\begin{array}{l}\text { Clotting factor con- } \\
\text { centrate. }\end{array}$ & $\begin{array}{l}\text { Joint bleeds. } \\
\text { Radiological joint } \\
\text { score. }\end{array}$ & \\
\hline Kavakli 1997 & $\begin{array}{l}\text { Prospective observa- } \\
\text { tional study, both } \\
\text { historically and par- } \\
\text { allel group } \\
\text { controlled }\end{array}$ & $\begin{array}{l}\text { Country: Turkey. } \\
\text { cases: } 6 \text { with se- } \\
\text { vere hemophilia A, } 1 \\
\text { with severe } \\
\text { hemophilia B. Con- } \\
\text { trols = } 10\end{array}$ & $\begin{array}{l}\text { Clotting factor con- } \\
\text { centrate. 20-50 IU/ } \\
\mathrm{kg} \text { body weight } \\
\text { twice weekly }\end{array}$ & $\begin{array}{l}\text { Vital bleeds. Joint } \\
\text { bleeds. Days hospi- } \\
\text { talised. Or- } \\
\text { thopedic score. Ra- } \\
\text { diologic joint score. } \\
\text { Life quality }\end{array}$ & \\
\hline Kreuz 1998 & $\begin{array}{l}\text { Prospective observa- } \\
\text { tional study. }\end{array}$ & $\begin{array}{l}\text { Country: Germany. } \\
\text { Cases: previously } \\
\text { untreated patients } \\
\text { with moderate or se- } \\
\text { vere hemophilia A. } \\
\text { Enrolled: } 21\end{array}$ & $\begin{array}{l}\text { Clotting factor con- } \\
\text { centrate. }\end{array}$ & Joint bleeding. & \\
\hline Liesner 1996 & $\begin{array}{l}\text { Retrospective obser- } \\
\text { vational study. Sin- } \\
\text { gle arm. }\end{array}$ & $\begin{array}{l}\text { Coun- } \\
\text { try: UK. Cases: se- } \\
\text { vere hemophilia A } \\
\text { and B. Enrolled } 24 \\
\text { and 3, respectively }\end{array}$ & $\begin{array}{l}\text { Clotting factor con- } \\
\text { centrate. Prophy- } \\
\text { laxis regimen. }\end{array}$ & $\begin{array}{l}\text { Number of bleeding } \\
\text { episodes. }\end{array}$ & \\
\hline Lofqvist 1997 & $\begin{array}{l}\text { Retrospective obser- } \\
\text { vational study. }\end{array}$ & $\begin{array}{l}\text { Coun- } \\
\text { try: Sweden. Cases: } \\
\text { severe hemophilia A }\end{array}$ & $\begin{array}{l}\text { Clotting factor con- } \\
\text { centrate. Dose: } 25-\end{array}$ & $\begin{array}{l}\text { Orthopedic } \\
\text { joint scores. Radio- }\end{array}$ & \\
\hline
\end{tabular}




\begin{tabular}{|c|c|c|c|c|c|}
\hline & & $\begin{array}{l}\text { or B. Enrolled: } \\
\text { hemophilia } A=29 . \\
\text { Hemophilia } B=5\end{array}$ & $\begin{array}{l}40 \mathrm{IU} / \mathrm{kg} \text { body } \\
\text { weight. Hemophilia } \\
\text { A three times per } \\
\text { week. Hemophilia } \\
\text { B twice per week }\end{array}$ & logic joint scores. & \\
\hline $\begin{array}{l}\text { Manco-Johnson } \\
1994\end{array}$ & $\begin{array}{l}\text { Prospective observa- } \\
\text { tional study. }\end{array}$ & $\begin{array}{l}\text { Coun- } \\
\text { try: USA. Cases: se- } \\
\text { vere hemophilia A } \\
\text { and B. Enrolled: } \\
\text { hemophilia A = 13; } \\
\text { hemophilia B = } 1\end{array}$ & $\begin{array}{l}\text { Clotting factor con- } \\
\text { centrate. Dose: fac- } \\
\text { tor VIII } 20 \text { IU } / \mathrm{kg} \\
\text { body weight. factor } \\
\text { IX } 40 \mathrm{IU} / \mathrm{kg} \text { body } \\
\text { weight. Frequency: } \\
\text { Factor VIII three } \\
\text { times per week ( }= \\
6 \text { ), and every other } \\
\text { day (n = 7). Factor } \\
\text { IX twice per week }\end{array}$ & $\begin{array}{l}\text { Bleed- } \\
\text { ing episodes. Radio- } \\
\text { logic joint score. }\end{array}$ & \\
\hline Nilsson 1970 & $\begin{array}{l}\text { Retrospective obser- } \\
\text { vational with histor- } \\
\text { ical control. }\end{array}$ & $\begin{array}{l}\text { Country: Swe- } \\
\text { den. Cases: } 24 \text { with } \\
\text { hemophilia A. }\end{array}$ & $\begin{array}{l}\text { AHF freeze-dried } \\
\text { concentrate. }\end{array}$ & $\begin{array}{l}\text { Days of hospitalisa- } \\
\text { tion. }\end{array}$ & \\
\hline Nilsson 1976 & $\begin{array}{l}\text { Retrospective obser- } \\
\text { vational with histor- } \\
\text { ical control. }\end{array}$ & $\begin{array}{l}\text { Country: Swe- } \\
\text { den. Cases: } 29 \text { with } \\
\text { hemophilia A. }\end{array}$ & $\begin{array}{l}\text { AHF freeze-dried } \\
\text { concentrate. }\end{array}$ & $\begin{array}{l}\text { Orthopedic joint } \\
\text { score. }\end{array}$ & \\
\hline Nilsson 1992 & $\begin{array}{l}\text { Retrospective obser- } \\
\text { vational study. }\end{array}$ & $\begin{array}{l}\text { Coun- } \\
\text { try: Sweden. Cases: } \\
\text { severe hemophilia A } \\
\text { or B. Enrolled: } \\
\text { hemophilia A }=52 \text {. } \\
\text { hemophilia B = } 8\end{array}$ & $\begin{array}{l}\text { Clotting factor con- } \\
\text { centrate. } \\
\text { Dose: Hemophilia } \\
\text { A 24-40 IU/kg body } \\
\text { weight three time } \\
\text { per } \\
\text { week. Hemophilia } \\
\text { B 25-40 IU/kg body } \\
\text { weight twice weekly }\end{array}$ & $\begin{array}{l}\text { Orthope- } \\
\text { dic joint score. Ra- } \\
\text { diologic joint score. }\end{array}$ & \\
\hline Nemes 2007 & $\begin{array}{l}\text { Prospective, multi- } \\
\text { center, 3-part clini- } \\
\text { cal trial. }\end{array}$ & $\begin{array}{l}\text { Country: } \\
\text { Austria. Cases: se- } \\
\text { vere hemophilia A. } \\
\text { Enrolled: cases } 49 . \\
\text { Control } 17\end{array}$ & $\begin{array}{l}\text { Immunate } \\
\text { S/D. Dose: accord- } \\
\text { ing to pharmacoki- } \\
\text { netics evaluation }\end{array}$ & Bleeding frequency. & $\begin{array}{l}\text { Part 1:pharmacoki- } \\
\text { netics randomised } \\
\text { double-blind; } \\
\text { Part 2: prospective } \\
\text { observational study. } \\
\text { Subjects received in- } \\
\text { fusions with Immu- } \\
\text { nate S/D } \\
\text { Part 3: pharmacoki- } \\
\text { netics evaluation af- } \\
\text { ter } 14 \text { weeks }+/-7 \\
\text { days }\end{array}$ \\
\hline
\end{tabular}




\begin{tabular}{|c|c|c|c|c|}
\hline Petrini 1991 & $\begin{array}{l}\text { Retrospective obser- } \\
\text { vational study. }\end{array}$ & $\begin{array}{l}\text { Coun- } \\
\text { try: Sweden. Cases: } \\
\text { severe hemophilia A } \\
\text { born in } 1965-1972 \\
\text { treated initially on- } \\
\text { demand. Controls: } \\
\text { severe hemophilia A } \\
\text { born } 1976 \text { - } 1983 \\
\text { treated prophylacti- } \\
\text { cally. Enrolled: } \\
\text { Cases: } 7 \text {. Controls: } \\
7\end{array}$ & $\begin{array}{l}\text { Clotting factor con- } \\
\text { centrate. }\end{array}$ & $\begin{array}{l}\text { Bleed fre- } \\
\text { quency. Limitation } \\
\text { of joint movement. } \\
\text { Ankle hemarthrosis }\end{array}$ \\
\hline Petrini 2001 & $\begin{array}{l}\text { Retrospective obser- } \\
\text { vational study. His- } \\
\text { torical control. }\end{array}$ & $\begin{array}{l}\text { Coun- } \\
\text { try: Sweden. Cases: } \\
\text { severe hemophilia A } \\
\text { or B, born 1988- } \\
\text { 1998. Enrolled: } 34\end{array}$ & $\begin{array}{l}\text { Clotting factor con- } \\
\text { centrate. Dose: } 20- \\
40 \text { IU/kg body } \\
\text { weight. Hemophilia } \\
\text { A three times per } \\
\text { week. Hemophilia } \\
\text { B twice per week }\end{array}$ & $\begin{array}{l}\text { Joint bleeds. } \\
\text { Hemarthrosis. }\end{array}$ \\
\hline Pettersson 1981 & $\begin{array}{l}\text { Retrospective obser- } \\
\text { vational study. His- } \\
\text { torical control. }\end{array}$ & $\begin{array}{l}\text { Country: Sweden. } \\
\text { Cases: } 44 \text { with se- } \\
\text { vere hemophiliaA. } 6 \\
\text { with severe } \\
\text { hemophilia B }\end{array}$ & $\begin{array}{l}\text { Hemophilia A: } \\
\text { AHF-Kabi. } \\
\text { Hemophilia B: Pre- } \\
\text { conativ } \\
\text { (KabiVitrum) }\end{array}$ & $\begin{array}{l}\text { Radiological joint } \\
\text { score. }\end{array}$ \\
\hline Ramsay 1973 & $\begin{array}{l}\text { Prospective observa- } \\
\text { tional study. }\end{array}$ & $\begin{array}{l}\text { Coun- } \\
\text { try: UK. Cases: se- } \\
\text { vere hemophilia A } \\
\text { or B. Enrolled: } \\
\text { Hemophilia A = 2, } \\
\text { Hemophilia B =1 }\end{array}$ & $\begin{array}{l}\text { Clotting factor con- } \\
\text { centrate: } \\
\text { cryoprecipitate. }\end{array}$ & Bleeding episodes. \\
\hline Royal 2002 & $\begin{array}{l}\text { Retrospective obser- } \\
\text { vational study. Par- } \\
\text { allel groups. }\end{array}$ & $\begin{array}{l}\text { Country: Europe. } \\
\text { Cases: prophylaxis } \\
\text { regimen (varies be- } \\
\text { tween HTC). Con- } \\
\text { trols: } \\
\text { demand. Enrolled: } \\
\text { Cases: } 313 \text {. Con- } \\
\text { trols: } 590\end{array}$ & $\begin{array}{l}\text { Clotting factor con- } \\
\text { centrate in prophy- } \\
\text { lactic or on-demand } \\
\text { regimen }\end{array}$ & $\begin{array}{l}\text { QoL Instrument: } \\
\text { SF-36. }\end{array}$ \\
\hline Schimpf 1977 & $\begin{array}{l}\text { Prospective observa- } \\
\text { tional study. Cross- } \\
\text { over study. }\end{array}$ & $\begin{array}{l}\text { Country: } \\
\text { Germany. Cases: se- } \\
\text { vere hemophilia A. } \\
\text { Enrolled: } 6 .\end{array}$ & $\begin{array}{l}\text { Clotting factor con- } \\
\text { centrate. Treatment } \\
\text { A: } 1 \text { x } 36 \mathrm{U} / \mathrm{kg} \\
\text { body weight and } \\
\text { week. Treatment B: } \\
2 \times 18 \mathrm{U} / \mathrm{kg} \text { body }\end{array}$ & Bleeding episodes. \\
\hline
\end{tabular}




\begin{tabular}{|c|c|c|c|c|}
\hline & & & $\begin{array}{l}\text { weight and week. } \\
\text { Treatment C: } 3 \times 12 \\
\text { U/kg body weight } \\
\text { and week }\end{array}$ & \\
\hline Schobess 2008 & $\begin{array}{l}\text { Prospective observa- } \\
\text { tional study. }\end{array}$ & $\begin{array}{l}\text { Country: Germany. } \\
\text { Cases: Preav- } \\
\text { iously untreated pa- } \\
\text { tients with severe } \\
\text { hemophilia A. En- } \\
\text { rolled: } 109 \text { ( } 42 \text { pri- } \\
\text { mary } \\
\text { prophylaxis: } 67 \text { sec- } \\
\text { ondary prophylaxis) }\end{array}$ & $\begin{array}{l}\text { At discretion of the } \\
\text { participating centre. } \\
\text { Median } 40 \mathrm{IU} / \mathrm{kg} \\
\text { twice a week }\end{array}$ & $\begin{array}{l}\text { Bleeding episodes } \\
\text { Joint preservation } \\
\text { Development of tar- } \\
\text { get joint }\end{array}$ \\
\hline Smith 1996 & $\begin{array}{l}\text { Retrospective obser- } \\
\text { vational switch } \\
\text { study. }\end{array}$ & $\begin{array}{l}\text { Coun- } \\
\text { try: USA. Cases: } \\
\text { episodic infusions. } \\
\text { Controls: prophy- } \\
\text { lactic infusions. En- } \\
\text { rolled: } 27 \text {. Controls } \\
=70\end{array}$ & $\begin{array}{l}\text { Clotting factor con- } \\
\text { centrate. }\end{array}$ & $\begin{array}{l}\text { Bleeding episodes. } \\
\text { Incremental cost ef- } \\
\text { fectiveness. }\end{array}$ \\
\hline Szucs 1996 & $\begin{array}{l}\text { Prospective observa- } \\
\text { tional study. }\end{array}$ & $\begin{array}{l}\text { Country: Germany. } \\
\text { Cases: moderate or } \\
\text { severe } \\
\text { hemophilia. Num- } \\
\text { ber enrolled: mod- } \\
\text { erate }=4 \text {, severe }=46\end{array}$ & $\begin{array}{l}\text { Clotting factor con- } \\
\text { centrate. Treatment } \\
\text { programs: (i) on-de- } \\
\text { mand; (ii) pure pro- } \\
\text { phylaxis; (iii) modi- } \\
\text { fied prophylaxis }\end{array}$ & $\begin{array}{l}\text { Joint bleeds. QoL } \\
\text { (SF-36). Cost of } \\
\text { care. Cost effective- } \\
\text { ness. }\end{array}$ \\
\hline Tagliaferri 2008 & $\begin{array}{l}\text { Retrospective obser- } \\
\text { vational switch } \\
\text { study. }\end{array}$ & $\begin{array}{l}\text { Country: } \\
\text { Italy. Cases: adoles- } \\
\text { cents and adults se- } \\
\text { vere hemophilia pa- } \\
\text { tients. Number en- } \\
\text { rolled }=84\end{array}$ & $\begin{array}{l}\text { Clotting factor con- } \\
\text { centrate. }\end{array}$ & $\begin{array}{l}\text { Joint bleeds. Ortho- } \\
\text { pedic and radiologic } \\
\text { score, } \\
\text { QoL, days lost from } \\
\text { work/school, usage } \\
\text { of clotting factor } \\
\text { concentrates }\end{array}$ \\
\hline Tusell 2002 & $\begin{array}{l}\text { Retrospective obser- } \\
\text { vational study. }\end{array}$ & $\begin{array}{l}\text { Country: } \\
\text { Spain. Cases: severe } \\
\text { hemophilia A or B. } \\
\text { Enrolled: } \\
\text { Hemophilia A = } \\
\text { 423. Hemophilia B } \\
=88\end{array}$ & $\begin{array}{l}\text { Clotting factor con- } \\
\text { centrate. }\end{array}$ & Bleeding episodes. \\
\hline Van den Berg 2001 & $\begin{array}{l}\text { Retrospective obser- } \\
\text { vational study. Sin- } \\
\text { gle arm. }\end{array}$ & $\begin{array}{l}\text { Country: Nether- } \\
\text { lands. Case: severe } \\
\text { hemophilia A or B. } \\
\text { Enrolled: }\end{array}$ & $\begin{array}{l}\text { Clotting factor con- } \\
\text { centrate. }\end{array}$ & Bleeding episodes. \\
\hline
\end{tabular}




\begin{tabular}{|c|c|c|c|c|}
\hline & & $\begin{array}{l}\text { hemophilia } A=70 \\
\text { hemophilia } B=5\end{array}$ & & \\
\hline Wu 2011 & $\begin{array}{l}\text { Prospective observa- } \\
\text { tional study. Single } \\
\text { arm. }\end{array}$ & $\begin{array}{l}\text { Coun- } \\
\text { try: China. Case: } \\
\text { severe and moder- } \\
\text { ate hemophilia. En- } \\
\text { rolled: Hemophilia } \\
\mathrm{A}=34\end{array}$ & $\begin{array}{l}\text { Clotting factor con- } \\
\text { centrate. Low dose } \\
(10 \mathrm{IU} / \mathrm{kg} / \mathrm{x} 2 \text { week })\end{array}$ & $\begin{array}{l}\text { Bleeding episodes. } \\
\text { Cost effectiveness. }\end{array}$ \\
\hline
\end{tabular}

IU: international units

QoL: quality of life

A P PENDICES

\section{Appendix I. Search strategies for current version of the review}

\begin{tabular}{|c|c|}
\hline Database & Strategy \\
\hline $\begin{array}{l}\text { The Cochrane Central Register of Controlled Trials (CENTRAL) } \\
\text { Issue 4, } 2010\end{array}$ & $\begin{array}{l}\# 1 \text { hemophilia } \\
\# 2 \text { haemophilia } \\
\# 3 \text { (\#1 or \#2) }\end{array}$ \\
\hline $\begin{array}{l}\text { MEDLINE (Ovid) } \\
2003 \text {-14th Feb } 2011\end{array}$ & 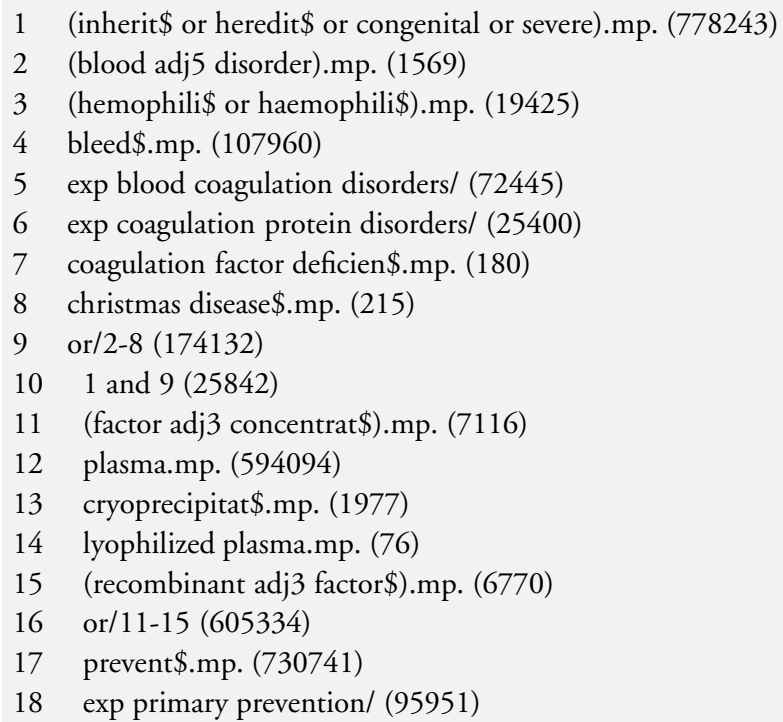 \\
\hline
\end{tabular}


19 prophyla\$.mp. (104804)

20 or/17-19 (878004)

21 ("factor 8" or "Factor 8" or "f viii" or "f VIII" or "F VIII" or fviii or fVIII or FVIII or f-viii or f-VIII or F-VIII or "factor viii" or "factor VIII" or "Factor VIII" or "factor 9" or "Factor 9" or "f ix" or "f IX" or "F IX" or fix or fIX or FIX or f-ix or f-IX or F-IX or "factor ix" or "factor IX" or "Factor IX").mp. (27545)

22 and $/ 10,16,20-21$ (279)

$2322(279)$

24 limit 23 to $\mathrm{yr}=$ "2003 -Current" (145)

EMBASE (Ovid)

2003 - 14th Feb 2011

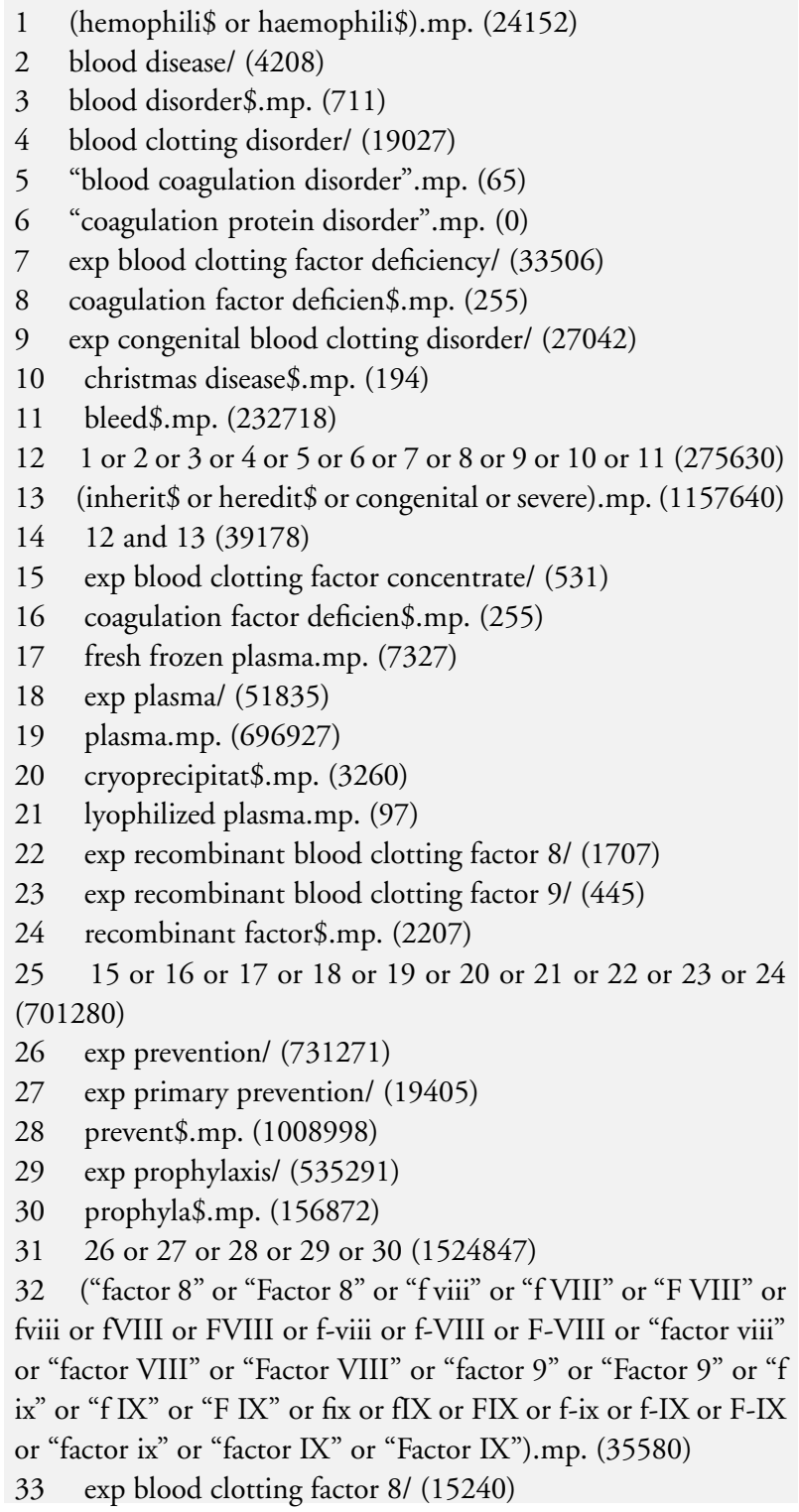

Clotting factor concentrates given to prevent bleeding and bleeding-related complications in people with hemophilia A or B (Review) 


\section{Appendix 2. Search strategies for previous versions of the review}

\begin{tabular}{l|l}
\hline Database & Strategy \\
\hline The Cochrane Central & $\# 1$ Therapeutics \\
Register of Controlled & $\# 2$ Intervention studies \\
Trials (CENTRAL) & $\# 3\left(\right.$ therap* or intervention* or treat*) $^{*}$ \\
$1948-2003$ & $\# 4(\# 1$ or \#2 or \#3) \\
& $\# 51$ hemophilia \\
& $\# 62$ haemophilia \\
& $\# 73(\# 51$ or \#62) \\
& $\# 8(\# 4$ and \#7) \\
\hline
\end{tabular}

MEDLINE (Ovid)

Jan 1966-May 2003

1. (inherit\$ or heredit\$ or congenital).mp.

2. (blood adj5 disorder).mp.

3. (hemophili\$ or haemophili\$).mp.

4. bleed\$.mp.

5. exp blood coagulation disorders/

6. exp coagulation protein disorders/

7. coagulation factor deficien $\$ . m p$.

8. christmas disease $\$ . m p$.

9. or $/ 2-8$

10. 1 and 9

11. (factor adj3 concentrat\$).mp.

12. plasma.mp.

13. cryoprecipitat\$.mp.

14. lyophilized plasma.mp.

15. (recombinant adj3 factor\$).mp.

16. or/11-15

17. prevent\$.mp.

18. exp primary prevention/

19. prophyla\$.mp.

20. or/17-19

21. ("factor 8" or "f viii" or fviii or "factor viii" or "factor 9" or "f ix" or fix or "factor ix").mp.

22. and $/ 10,16,20-21$

EMBASE (Ovid)

1988- May 2003
1. (hemophili\$ or haemophili\$).mp.

2. blood disease/

3. blood disorder\$.mp.

4. blood disorder\$.mp. 
5. blood clotting disorder/

6. "blood coagulation disorder".mp.

7. “coagulation protein disorder".mp.

8. exp blood clotting factor deficiency/

9. coagulation factor deficien\$.mp.

10. exp congenital blood clotting disorder/

11. christmas disease $\$ . m p$.

12. bleed \$.mp.

13. or/1-12

14. (inherit $\$$ or heredit $\$$ or congenital).mp.

15. 13 and 14

16. exp blood clotting factor concentrate/

17. coagulation factor deficien\$.mp.

18. fresh frozen plasma.mp.

19. exp plasma/

20. plasma.mp.

21. cryoprecipitat\$.mp.

22. lyophilized plasma.mp.

23. exp recombinant blood clotting factor $8 /$

24. exp recombinant blood clotting factor $9 /$

25. recombinant factor $\$ . \mathrm{mp}$.

26. or/16-25

27. exp prevention/

28. exp primary prevention/

29. prevent\$.mp.

30. exp prophylaxis/

31. prophyla\$.mp.

32. or/27-31

33. ("factor 8 " or "f viii" or fviii or "factor viii" or "factor 9" or "f ix" or fix or "factor ix").mp.

34. exp blood clotting factor $8 /$

35. exp blood clotting factor $9 /$

36. or/33-35

37. and $/ 15,26,32,36$

\section{WHAT'S NEW}

Last assessed as up-to-date: 9 July 2011.

\begin{tabular}{lll}
\hline Date & Event & Description \\
\hline 10 July 2011 & New search has been performed & $\begin{array}{l}\text { Two new trials have been incorporated into the review } \\
\text { (Gringeri 2011; Manco-Johnson 2007). }\end{array}$
\end{tabular}

Clotting factor concentrates given to prevent bleeding and bleeding-related complications in people with hemophilia A or B (Review) 
10 July 2011 New citation required and conclusions have changed

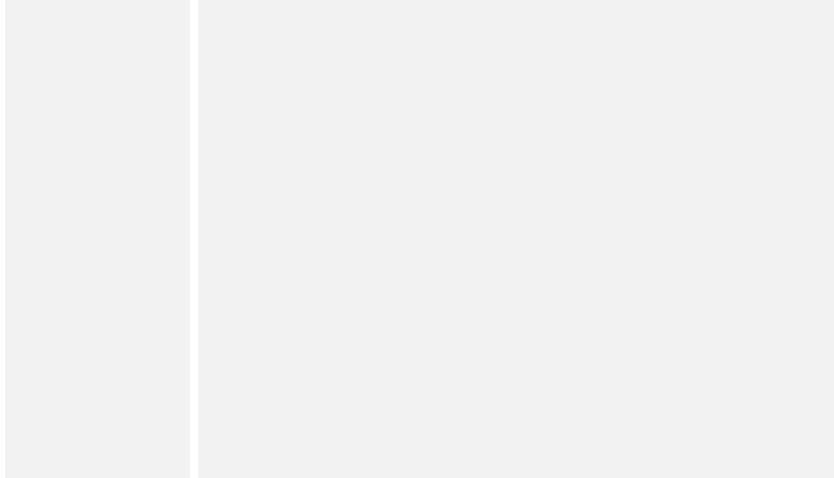

The conclusions of the review have changed from there being insufficient evidence assessing the use of prophylactic clotting factor concentrates, to there being evidence that the use of these concentrates is effective in decreasing the frequency of joint bleeds and in partially preventing or slowing down the development of arthropathy

The number of participants included in the review has increased from 37 to 142 , with two new studies added

Alfonso Iorio (previously a co-author) is now lead author on this review and Kent Stobart (previously lead-author) is now a co-author. John Wu has stepped down from the review and Emanuela Marchesini, Maura Marcucci and Anthony Chan are new co-authors

\section{H I S T O R Y}

Protocol first published: Issue 1, 2002

Review first published: Issue 2, 2005

\begin{tabular}{l|l|l}
\hline Date & Event & Description \\
\hline 7 October 2009 & Amended & $\begin{array}{l}\text { Please note: } \\
\text { We are aware that the update of this review is overdue. The original review } \\
\text { team has stepped down and a new review team is in place and working on the } \\
\text { update. The updated version of this review will be published in } 2010\end{array}$ \\
\hline 31 October 2008 & Amended & Converted to new review format. \\
\hline 1 February 2006 & New search has been performed & $\begin{array}{l}\text { The text of the Reviewers' Conclusions in the abstract has been altered to } \\
\text { make clear that there is a lack of evidence from randomised controlled trials } \\
\text { for the use of prophylaxis. }\end{array}$ \\
\hline
\end{tabular}




\section{CONTRIBUTIONSOFAUTHORS}

Kent Stobart: protocol development; study selection; data extraction; data entry; development of final review.

Alfonso Iorio: study selection; data extraction; development of final review.

John K. Wu (previous author): protocol development.

New roles in the update

Alfonso Iorio: updated manuscript drafting; development of final review.

Emanuela Marchesini: study selection; data extraction; updated manuscript drafting; development of final review.

Maura Marcucci: study selection; data extraction.

Anthony Chan: development of final review.

Kent Stobart: development of final review.

\section{DECLARATIONSOF INTEREST}

None known.

\section{SOURCES OF SUPPORT}

\section{Internal sources}

- Alberta Research Centre for Child Health Evidence, Canada.

This support was received for the firs edition of this systematic review

\section{External sources}

- Association of Hemophilia Clinic Directors of Canada, Canada.

This support was received for the firs edition of this systematic review

\section{DIFFERENCES BETWEEN PROTOCOLANDREVIEW}

In the 2011 update we undertook a post hoc sensitivity analyse for adverse events.

\section{NDEX TERMS}

\section{Medical Subject Headings (MeSH)}

Blood Coagulation Factors [*therapeutic use]; Factor VIII [*therapeutic use]; Hemarthrosis [* prevention \& control]; Hemophilia A [* complications]; Hemophilia B [*complications]; Randomized Controlled Trials as Topic 


\section{MeSH check words}

Humans

Clotting factor concentrates given to prevent bleeding and bleeding-related complications in people with hemophilia A or B (Review) Copyright $\odot 20$ I I The Cochrane Collaboration. Published by John Wiley \& Sons, Ltd. 